\title{
Biological Activity of Triazolopyrimidine Copper(II) Complexes Modulated by an Auxiliary N-N-Chelating Heterocycle Ligands
}

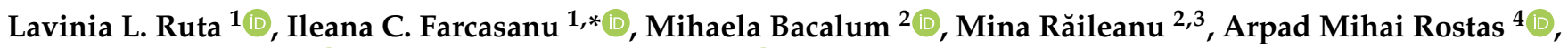 \\ Constantin Daniliuc ${ }^{5}\left(\right.$ D), Mariana Carmen Chifiriuc ${ }^{6}{ }^{\circledR}$, Luminița Măruțescu ${ }^{6}$, Marcela Popa ${ }^{6}$, Mihaela Badea ${ }^{7}$, \\ Emilia Elena Iorgulescu 8 () and Rodica Olar ${ }^{7, *}$
}

1 Department of Organic Chemistry, Biochemistry and Catalysis, Faculty of Chemistry, University of Bucharest, 90-92 Panduri Str., 050663 Bucharest, Romania; lavinia.ruta@chimie.unibuc.ro

2 Department of Life and Environmental Physics, Horia Hulubei National Institute for Physics and Nuclear Engineering, 30 Reactorului Str., 077125 Măgurele, Romania; bmihaela@nipne.ro (M.B.); mina.raileanu@nipne.ro (M.R.)

3 Department of Electricity, Solid State and Biophysics, Faculty of Physics, University of Bucharest, 405A Atomiştilor Str., 077125 Măgurele, Romania

4 Laboratory of Atomic Structures and Defects in Advanced Materials, National Institute of Materials Physics, 405A Atomiştilor Str., 077125 Măgurele, Romania; arpad.rostas@infim.ro

5 Organisch-Chemisches Institute, Westfälische Wilhelms-Universität Münster, Corrensstrasse 40, 48149 Münster, Germany; constantin.daniliuc@uni-muenster.de

check for updates

Citation: Ruta, L.L.; Farcasanu, I.C.; Bacalum, M.; Răileanu, M.; Rostas, A.M.; Daniliuc, C.; Chifiriuc, M.C.; Măruțescu, L.; Popa, M.; Badea, M.; et al. Biological Activity of Triazolopyrimidine Copper(II) Complexes Modulated by an Auxiliary N-N-Chelating Heterocycle Ligands. Molecules 2021, 26, 6772. https://doi.org/10.3390/ molecules 26226772

Academic Editors: Franco Bisceglie and Gianantonio Battistuzzi

Received: 29 September 2021 Accepted: 5 November 2021 Published: 9 November 2021

Publisher's Note: MDPI stays neutral with regard to jurisdictional claims in published maps and institutional affiliations.

Copyright: () 2021 by the authors. Licensee MDPI, Basel, Switzerland. This article is an open access article distributed under the terms and conditions of the Creative Commons Attribution (CC BY) license (https:// creativecommons.org/licenses/by/ $4.0 /)$.
6 Department of Microbiology, Faculty of Biology, University of Bucharest, 1-3 Aleea Portocalelor Str., 060101 Bucharest, Romania; carmen.chifiriuc@bio.unibuc.ro (M.C.C.); luminita.marutescu@bio.unibuc.ro (L.M.); marcela.popa@bio.unibuc.ro (M.P.)

7 Department of Inorganic Chemistry, Biochemistry and Catalysis, Faculty of Chemistry, University of Bucharest, 90-92 Panduri Str., 050663 Bucharest, Romania; mihaela.badea@chimie.unibuc.ro

8 Department of Analytical Chemistry, Faculty of Chemistry, University of Bucharest, 90-92 Panduri Str., 050663 Bucharest, Romania; emilia-elena.iorgulescu@chimie.unibuc.ro

* Correspondence: ileana.farcasanu@chimie.unibuc.ro (I.C.F.); rodica.olar@chimie.unibuc.ro (R.O.)

Abstract: Novel complexes of type $\left[\mathrm{Cu}(\mathrm{N}-\mathrm{N})(\mathrm{dmtp})_{2}\left(\mathrm{OH}_{2}\right)\right]\left(\mathrm{ClO}_{4}\right)_{2} \cdot \mathrm{dmtp}\left((\mathbf{1}) \mathrm{N}-\mathrm{N}: 2,2^{\prime}\right.$-bipyridine; (2) L: 1,10-phenantroline and dmtp: 5,7-dimethyl-1,2,4-triazolo[1,5-a]pyrimidine) were designed in order to obtain biologically active compounds. Complexes were characterized as mononuclear species that crystallized in the space group P-1 of the triclinic system with a square pyramidal geometry around the copper (II). In addition to the antiproliferative effect on murine melanoma B16 cells, complex (1) exhibited low toxicity on normal BJ cells and did not affect membrane integrity. Complex (2) proved to be a more potent antimicrobial in comparison with (1), but both compounds were more active in comparison with dmtp-both against planktonic cells and biofilms. A stronger antimicrobial and antibiofilm effect was noticed against the Gram-positive strains, including methicillin-resistant Staphylococcus aureus (MRSA). Both electron paramagnetic resonance (EPR) and Saccharomyces cerevisiae studies indicated that the complexes were scavengers rather than reactive oxygen species promoters. Their DNA intercalating capacity was evidenced by modifications in both absorption and fluorescence spectra. Furthermore, both complexes exhibited nuclease-like activity, which increased in the presence of hydrogen peroxide.

Keywords: copper(II) complex; 1,2,4-triazolo[1,5-a]pyrimidine; cytotoxicity; biofilm; metallonuclease activity; DNA intercalation

\section{Introduction}

The triazolopyrimidine derivatives are valuable pharmacophores based on their resemblance to purine bases. As result, several compounds bearing diverse substituents were developed as species with relevant biological activity [1]. The most recent findings in the field describe triazolopyrimidines as agents with potent antiproliferative activity by inducing G0/G1 phase arrest [2] or cellular apoptosis [3], as species with anti-HIV activity [4], 
as SARS-CoV-2 main protease inhibitors [5], and as antimicrobials [6,7]. Additionally, it is believed that triazolopyrimidines are promising candidates for treating Alzheimer's disease and related neurodegenerative tauopathies [8].

A promising activity, comparable with that of standard anticancer drugs, against a panel of cancer cell lines was reported for $[1,2,4]$ triazolo[ $[1,5-a]$ pyrimidine derivatives (tpds). Among these, some pyrimidine ring-disubstituted species exhibit a good activity against colon (HCT116) [9], human promyelocytic leukemia (HL60) [10], gastric (MGC803), esophageal (EC 109), lung (A549 and PC-9) [11], liver (HepG2) [12] and breast (MCF7) $[12,13]$ cancer cell lines. It is worth mentioning that most of these lines are not sensitive to inorganic drugs such as cisplatin and related derivatives.

A significant antibacterial activity, comparable with that of standard antimicrobials against Staphylococcus aureus, Escherichia coli [14,15], Bacillus subtilis [14] and Pseudomonas aeruginosa [15] strains was also reported for some substituted tpds.

Considering its biological potency, the tp scaffold is often used to develop biologically active complexes, with a net preference for $\mathrm{Cu}$ (II) against other metal ions. Copper(II) exhibits particular traits, such as borderline acid characteristics or stereochemical and oxidation state versatility [16]. Moreover, most of the $\mathrm{Cu}(\mathrm{II})$ complexes with tps were reported as having antiparasitic [17], antitumor, or antimicrobial activity [18].

Among the antiparasitic compounds, $\left[\mathrm{Cu}_{2}(\mu-7 \mathrm{atp})_{4} \mathrm{Cl}_{2}\right] \mathrm{Cl}_{2} \cdot 4 \mathrm{H}_{2} \mathrm{O}$, $\left[\mathrm{Cu}_{2}(\mu-7 \mathrm{atp})_{4}\left(\mathrm{H}_{2} \mathrm{O}\right)_{2}\right]$ $\left(\mathrm{NO}_{3}\right) \cdot 4 \mathrm{H}_{2} \mathrm{O}$ (7atp: 7-amino-1,2,4-triazolo[1,5-a]pyrimidine) [19], [ $\left.\mathrm{Cu}_{2}(\mathrm{dmtp})_{4} \mathrm{Cl}_{4}\right] 2 \mathrm{H}_{2} \mathrm{O}$ [20], $\left[\mathrm{Cu}(\mathrm{dmtp})_{4}\left(\mathrm{H}_{2} \mathrm{O}\right)_{2}\right]\left(\mathrm{ClO}_{4}\right)_{2} \cdot 2 \mathrm{H}_{2} \mathrm{O}$ [21], and [Cu(dmtp $\left.)_{2}\left(\mathrm{NO}_{3}\right)_{2}\left(\mathrm{H}_{2} \mathrm{O}\right)\right]$ (dmtp: 5,7-dimethyl1,2,4-triazolo[1,5-a]pyrimidine) [22] showed a substantial in vitro activity against Leishmania spp. and Trypanosoma cruzi. Additionally, low toxicity against macrophage host cells was observed for all complexes.

A good antiproliferative activity against $L$. infantum and L. braziliensis was also observed for $\left[\mathrm{Cu}(\mathrm{HmtpO})_{2}\left(\mathrm{H}_{2} \mathrm{O}\right)_{3}\right]\left(\mathrm{ClO}_{4}\right)_{2} \mathrm{H}_{2} \mathrm{O}$ and $\left\{\left[\mathrm{Cu}(\mathrm{HmtpO})_{2}\left(\mathrm{H}_{2} \mathrm{O}\right)_{2}\right]\left(\mathrm{ClO}_{4}\right)_{2} 2 \mathrm{HmtpO}\right\}_{\mathrm{n}}$ (HmtpO: 5-methyl-1,2,4-triazolo[1,5-a]pyrimidin-7(4H)-one)—complexes that affect the metabolism of the parasites at the level of both NAD+/NADH balance and organelle membranes, causing the cell death [23].

Moreover, complexes with mixed ligands such as $\left[\mathrm{Cu}\left(\mathrm{H}_{2} \mathrm{O}\right)(\mathrm{phen})(\mathrm{tp})_{2}\right]\left(\mathrm{ClO}_{4}\right)_{2} \cdot \mathrm{H}_{2} \mathrm{O}$ and $\left[\mathrm{Cu}\left(\mathrm{NO}_{3}\right)\left(\mathrm{H}_{2} \mathrm{O}\right)(\right.$ phen $\left.)(\mathrm{tp})\right]\left(\mathrm{NO}_{3}\right)$ (phen: 1,10-phenanthroline) [24] inhibit in vitro epimastigote forms of T. cruzi and promastigotes of L. peruviana, while $\left[\mathrm{Cu}(\mathrm{dmtp})_{2}(\mathrm{bpym})\right.$ $\left.\left(\mathrm{H}_{2} \mathrm{O}\right)_{2}\right]\left(\mathrm{ClO}_{4}\right)_{2} 2 \mathrm{H}_{2} \mathrm{O}$ and $\left[\mathrm{Cu}_{2}(\text { tp })_{2}(\text { bpym })_{2}(\mu\right.$-bpym $\left.)\left(\mathrm{ClO}_{4}\right)_{2}\right]\left(\mathrm{ClO}_{4}\right)_{2}$ (bpym: 2,2'-bipyrimidine) exhibit activity against the same parasites, which cause leishmaniasis and Chagas disease, respectively [25].

A broad spectrum of antimicrobial activity was demonstrated by $\left[\mathrm{Cu}_{2}(\mathrm{pmtp})_{2} \mathrm{Cl}_{4}\left(\mathrm{OH}_{2}\right)_{2}\right]$ [26], $\left[\mathrm{Cu}\right.$ (pmtp) $\left.\left(\mathrm{CH}_{3} \mathrm{COO}\right)_{2}\right] 0.5 \mathrm{H}_{2} \mathrm{O}$ [27] and [Cu(pmtp) $\left.\left(\mathrm{OH}_{2}\right)_{3}\right]\left(\mathrm{ClO}_{4}\right) 3 \mathrm{H}_{2} \mathrm{O}$ (pmtp: 5-phenyl-7methyl-1,2,4-triazolo[1,5-a]pyrimidine) [28] against both planktonic and biofilm-embedded strains. It is worth mentioning the activity of all complexes against methicillin-resistant $S$. aureus (MRSA). Moreover, complexes with mixed ligands $\left[\mathrm{Cu}(\mathrm{N}-\mathrm{N})_{2}(\mathrm{pmtp})\right]\left(\mathrm{ClO}_{4}\right)_{2}(\mathrm{~N}-\mathrm{N}$ : 2,2'-bipyridine (bpy) and phen) showed antibacterial potential against several bacterial strains, including MRSA, the extended-spectrum beta-lactamase (ESBL)-producing E. coli 5, and the multi-drug-resistant P. aeruginosa 9027 , both in planktonic and biofilm growth state [18].

Among these species, $\left[\mathrm{Cu}(\mathrm{pmtp})\left(\mathrm{CH}_{3} \mathrm{COO}\right)_{2}\right] 0.5 \mathrm{H}_{2} \mathrm{O}$ and $\left[\mathrm{Cu}(\mathrm{pmtp})\left(\mathrm{OH}_{2}\right)_{3}\right]\left(\mathrm{ClO}_{4}\right) 3 \mathrm{H}_{2} \mathrm{O}$ also induce a decrease in the DNA content of cells in the G0/G1 phase in a human colon adenocarcinoma cell line (HT 29) [27], while $\left[\mathrm{Cu}(\mathrm{N}-\mathrm{N})_{2}(\mathrm{pmtp})\right]\left(\mathrm{ClO}_{4}\right)_{2}$ exhibited excellent activity against B16 murine melanoma cells, that in addition, is accompanied by a lack of cytotoxicity against healthy BJ cells [18].

Concerning species with $\mathrm{N}-\mathrm{N}$ derivatives, we have recently shown that $\left\{\left[\mathrm{Cu}(\mathrm{bpy})_{2}\right.\right.$ $\left.\left.\left(\mu_{2} \mathrm{OClO}_{3}\right)\right] \mathrm{ClO}_{4}\right\}_{\mathrm{n}}$ exhibits a selective cytotoxicity against $\mathrm{B} 16$ cells while $\left[\mathrm{Cu}(\mathrm{phen})_{2}\left(\mathrm{OH}_{2}\right)\right]$ $\left(\mathrm{ClO}_{4}\right)_{2}$ proved to be a very potent antibacterial agent against both susceptible and resistant Gram-positive and Gram-negative strains, in planktonic or biofilm growth states [29]. 
By combining these $\mathrm{N}-\mathrm{N}$ heterocycles with a disubstituted tp derivative we succeded in improving the antimicrobial activity of $\mathrm{Cu}$ (II) complexes [18].

In an attempt to modulate the biological activity of dmtp $\mathrm{Cu}$ (II) complexes through such N-N derivatives, we present here new complexes with mixed ligands of $[\mathrm{Cu}(\mathrm{N}-$ $\left.\mathrm{N})(\mathrm{dmtp})_{2}\left(\mathrm{OH}_{2}\right)\right]\left(\mathrm{ClO}_{4}\right)_{2} \mathrm{dmtp}(\mathrm{N}-\mathrm{N}$ : bpy (1) and phen (2)) type that were fully characterized by single-crystal $\mathrm{X}$-ray analysis and spectroscopic methods. In addition, data regarding the antitumor and antimicrobial activity of these complexes are also included, together with that concerning their potential mechanisms of action.

\section{Results and Discussion}

A new series of copper(II) complexes with mixed ligands 2,2'-bipyridine (bpy) or 1,10-phenanthroline (phen) and 5,7-dimethyl-1,2,4-triazolo[1,5-a]pyrimidine (dmtp) were synthesized by stepwise reactions, as depicted in Scheme 1 .

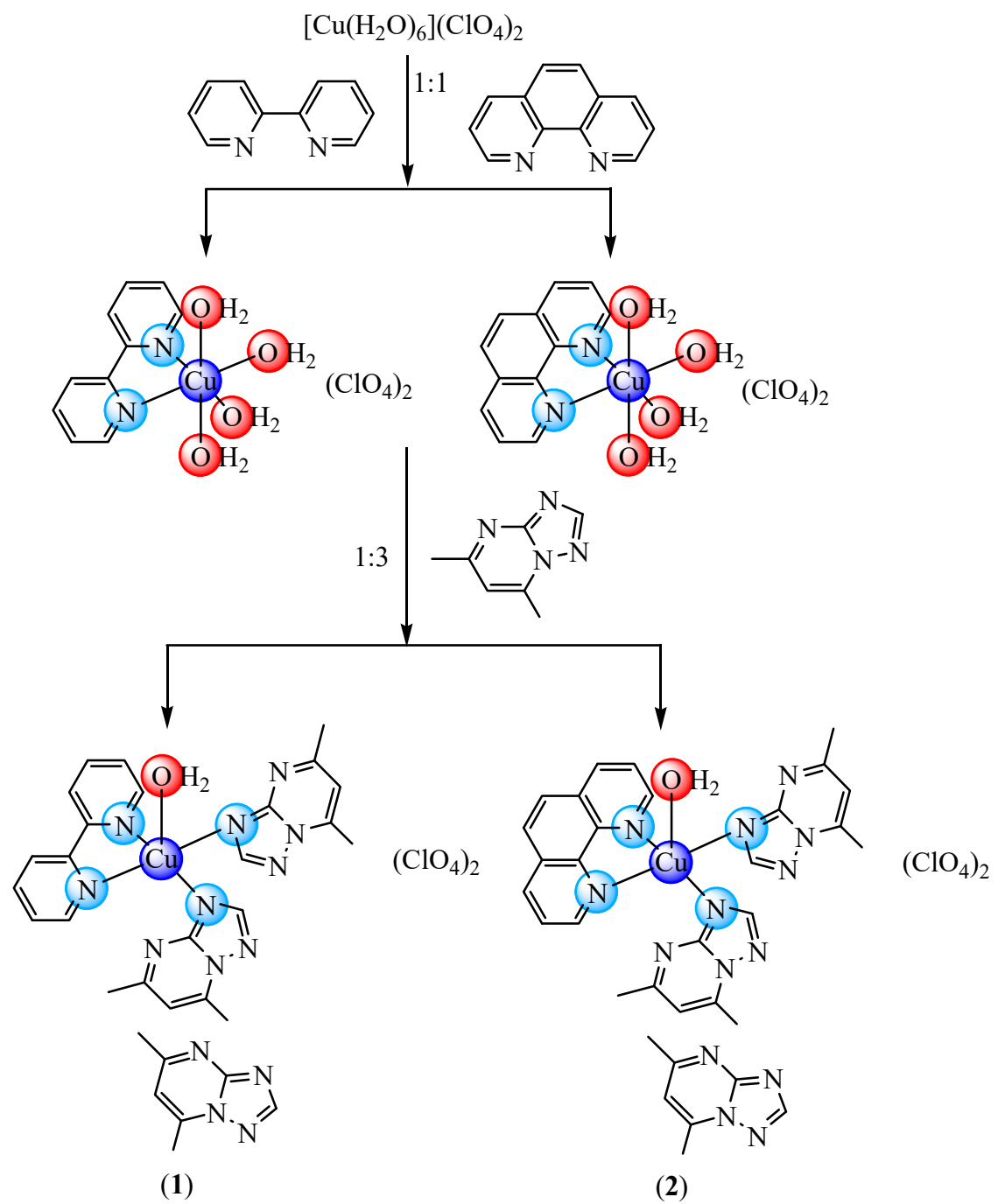

Scheme 1. The route of complexes [Cu(bpy) $\left.(\mathrm{dmtp})_{2}\left(\mathrm{OH}_{2}\right)\right]\left(\mathrm{ClO}_{4}\right)_{2} \cdot \mathrm{dmtp}(\mathbf{1})$ and $\left[\mathrm{Cu}(\mathrm{phen})(\mathrm{dmtp})_{2}\right.$ $\left.\left(\mathrm{OH}_{2}\right)\right]\left(\mathrm{ClO}_{4}\right)_{2} \cdot \operatorname{dmtp}(2)$ synthesis.

First, the $[\mathrm{Cu}(\mathrm{N}-\mathrm{N})]^{2+}$ intermediates were prepared, and then the dmtp was added in a suitable molar ratio. The compounds were characterized as mononuclear species by single-crystal X-ray diffraction, elemental analysis, EPR, FTIR, and UV-Vis spectra, as well as cyclic voltammetry. 


\subsection{Description of the Crystal Structure of $\mathrm{Cu}(\mathrm{II})$ Complexes}

The structures of both complexes (1) and (2) were resolved by single-crystal X-ray diffraction, and a summary of crystallographic data is presented in Table 1. These compounds crystallize in the space group $P-1$ of the triclinic crystal system. The asymmetric unit consists of a cationic unit containing the $\mathrm{Cu}$ (II) ion, two perchlorate anions, and one uncoordinated 5,7-dimethyl-1,2,4-triazolo[1,5-a]pyrimidine (dmtp) ligand (Figure 1). For both complexes, the coordination geometry around the $\mathrm{Cu}$ (II) ion is square pyramidal, with the $\mathrm{Cu}(\mathrm{II})$ located in the basal plane as indicated by the continuous shape measure (CShM) values of 0.670 for (1) and 0.603 for (2) (Supplementary Table S1). Two corners of the basal plane are occupied by the bpy ligand, which coordinates in a chelate fashion with $\mathrm{Cu}-\mathrm{N}$ bonds length of 2.031(2)/2.020(2) and 2.018(2)/2.038(2) $\AA$, respectively. The other two corners of the basal plane are occupied by two unidentate dmtp ligands that generate $\mathrm{Cu}-\mathrm{N}$ bonds with a length of 2.004(2)/1.989(2) and 1.991(2)/1.985(2) $\AA$, respectively. A coordinated water molecule occupies the axial position of the square pyramidal surrounding with a Cu-O bond length of 2.233(2)/2.234(2) $\AA$ (Table 2).

Table 1. Crystal data and structure refinement for compounds (1) and (2).

\begin{tabular}{|c|c|c|}
\hline Compound & (1) & (2) \\
\hline Empirical formula & $\mathrm{C}_{31} \mathrm{H}_{34} \mathrm{Cl}_{2} \mathrm{CuN}_{14} \mathrm{O}_{9}$ & $\mathrm{C}_{33} \mathrm{H}_{34} \mathrm{Cl}_{2} \mathrm{CuN}_{14} \mathrm{O}_{9}$ \\
\hline Formula weight $/ \mathrm{g} / \mathrm{mol}$ & 881.16 & 905.18 \\
\hline Temperature/K & $100(2)$ & $173(2)$ \\
\hline Crystal system & triclinic & triclinic \\
\hline Space group & $\mathrm{P}-1$ & $P-1$ \\
\hline $\mathrm{a} / \AA$ & $11.6764(3)$ & $11.5914(2)$ \\
\hline $\mathrm{b} / \AA$ & $12.1766(3)$ & $12.1725(2)$ \\
\hline$c / \AA$ & $14.4595(3)$ & $15.0547(3)$ \\
\hline$\alpha /{ }^{\circ}$ & $99.1420(10)$ & $96.2490(10)$ \\
\hline$\beta /{ }^{\circ}$ & $100.2900(10)$ & 99.9130(10) \\
\hline$\gamma /{ }^{\circ}$ & $105.2460(10)$ & $106.1710(10)$ \\
\hline Volume $/ \AA^{3}$ & $1905.14(8)$ & 1981.87(6) \\
\hline $\mathrm{Z}$ & 2 & 2 \\
\hline$\rho_{\text {calc }} / \mathrm{g} / \mathrm{cm}^{3}$ & 1.536 & 1.517 \\
\hline$\mu / \mathrm{mm}^{-1}$ & 2.721 & 0.757 \\
\hline $\mathrm{F}(000)$ & 906 & 930 \\
\hline Radiation $/ \AA$ & 1.54178 & 0.71073 \\
\hline Reflections collected & 27839 & 11206 \\
\hline Independent reflections & $6708[\mathrm{R}(\mathrm{int})=0.0367]$ & $7859[\mathrm{R}(\mathrm{int})=0.0413]$ \\
\hline Data/restraints/parameters & $6708 / 0 / 528$ & $7859 / 127 / 591$ \\
\hline Goodness-of-fit on $\mathrm{F}^{2}$ & 1.026 & 1.048 \\
\hline Final $R$ indexes $[\mathrm{I} \geq 2 \sigma(\mathrm{I})]$ & $\mathrm{R} 1=0.0330, \mathrm{wR} 2=0.0804$ & $\mathrm{R} 1=0.0529, \mathrm{wR} 2=0.1370$ \\
\hline Final $\mathrm{R}$ indexes [all data] & $\mathrm{R} 1=0.0368, \mathrm{wR} 2=0.0829$ & $\mathrm{R} 1=0.0589, \mathrm{wR} 2=0.1438$ \\
\hline $\begin{array}{c}\text { Largest diff. } \\
\text { Peak/hole/e } \AA^{-3}\end{array}$ & $0.490 /-0.376$ & $0.380 /-0.602$ \\
\hline
\end{tabular}

Table 2. Selected bond distances $(\AA)$ and bond angles $\left({ }^{\circ}\right)$ for $(\mathbf{1})$ and (2).

\begin{tabular}{|c|c|c|c|c|c|c|c|c|c|c|c|c|c|}
\hline \multicolumn{7}{|c|}{ (1) } & \multicolumn{7}{|c|}{ (2) } \\
\hline Cu1 & N1 & $2.031(2)$ & N1 & Cu1 & N2 & $80.65(6)$ & $\mathrm{Cu} 1$ & N1 & $2.020(2)$ & N1 & Cu1 & N2 & $81.52(9)$ \\
\hline $\mathrm{Cu} 1$ & N2 & $2.018(2)$ & N1 & Cu1 & N31 & $91.85(7)$ & Cu1 & N2 & $2.038(2)$ & N1 & Cu1 & N31 & $93.55(9)$ \\
\hline Cu1 & N21 & $2.004(2)$ & N1 & Cu1 & O1 & $93.63(6)$ & Cu1 & N21 & $1.989(2)$ & N1 & Cu1 & O1 & $91.43(9)$ \\
\hline Cu1 & N31 & $1.991(2)$ & N2 & Cu1 & N21 & $96.08(7)$ & Cu1 & N31 & $1.985(2)$ & $\mathrm{N} 2$ & Cu1 & N21 & 93.49(9) \\
\hline \multirow[t]{4}{*}{ Cu1 } & $\mathrm{O} 1$ & $2.233(2)$ & N2 & Cu1 & $\mathrm{O} 1$ & $92.14(6)$ & Cu1 & $\mathrm{O} 1$ & $2.234(2)$ & $\mathrm{N} 2$ & Cu1 & O1 & $88.69(9)$ \\
\hline & & & N21 & Cu1 & N31 & $90.34(7)$ & & & & N21 & Cu1 & N31 & $90.71(10)$ \\
\hline & & & N21 & Cu1 & O1 & $95.48(7)$ & & & & N21 & Cu1 & O1 & $93.47(10)$ \\
\hline & & & N31 & Cu1 & O1 & $94.40(6)$ & & & & N31 & Cu1 & O1 & $99.01(10)$ \\
\hline
\end{tabular}




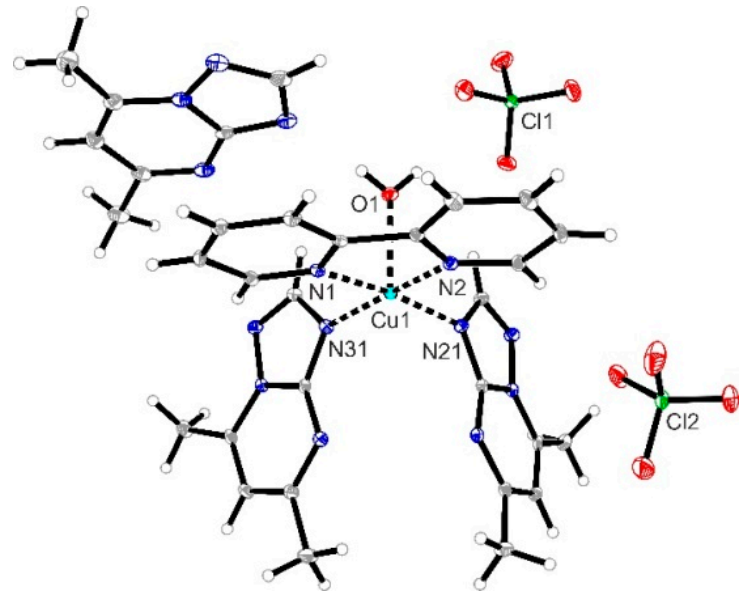

(a)

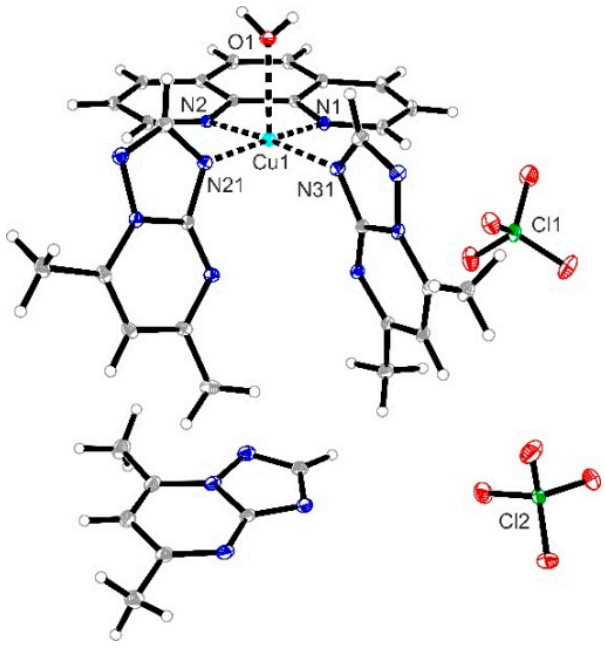

(b)

Figure 1. Crystal structures of compound (1) (a) and compound (2) (b). Thermal ellipsoids are set at 30\% (for (1)) and 15\% (for (2)) probability.

Remarkably, both complexes crystallized with an additional uncoordinated dmtp ligand molecule in the asymmetric unit. The analysis of the packing diagram of both complexes reveals the formation of dimers between the cationic units and the free dmtp ligands. The dimers for compound (1) are shown in Figure 2, while those for compound (2) are presented in Supplementary Figures S1 and S2.

In the solid state, a linear chain along the $b$-axis involving alternating $\pi \cdots \pi$ interactions between the bpy ligands of two cations $(C g 1 \cdots \operatorname{Cg} 13.377 \AA)$ and $\pi \cdots \pi$ interactions between a part of the bpy ligand and the five-member aromatic ring of the uncoordinated dmtp molecule (Cg2 ‥Cg $33.465 \AA$ ) was observed for complex (1) (Figure 2, Supplementary Table S2). Similar interactions involving alternating $\pi \cdots \pi$ interactions between the phen ligands of two complex moieties ( $C g 1 \cdots C g 13.594 \AA)$ and $\pi \cdots \pi$ interactions between a part of the phen and the five-member aromatic ring of the free dmtp (Cg2 …Cg3 $3.463 \AA$ ) can be noticed for complex (2) (Supplementary Figure S3, Supplementary Table S3).

\subsection{Physico-Chemical Characterization of Complexes \\ 2.2.1. FT-IR Spectra}

In the complexes spectra, the band associated with the triazolopyrimidine-fused rings (1632 and $1630 \mathrm{~cm}^{-1}$ ) is slightly shifted to lower wavenumbers in comparison with the free ligand (1635 $\mathrm{cm}^{-1}$; Supplementary Figure S4), as was observed for other complexes with tpds coordinated through the $\mathrm{N}^{3}$ atom [11]. The $\mathrm{N}-\mathrm{N}$-chelating heterocycle rings generate bands characteristic for overlapping $v(C=N)$ and $v(C=C)$ stretching vibrations in the 1440-1600 $\mathrm{cm}^{-1}$ range. Still, these bands display a low intensity along with that characteristic for a pyrimidine moiety. The intense bands at $1095 / 1099 \mathrm{~cm}^{-1}$ are assigned to $v_{3}\left(\mathrm{ClO}_{4}\right)$, and the medium ones at $623 / 624 \mathrm{~cm}^{-1}$ are assigned to $v_{4}\left(\mathrm{ClO}_{4}\right)$ stretching vibrations and account for perchlorate presence as a free ion [30]. The low-intensity bands at 417 and $432 \mathrm{~cm}^{-1}$ come from $v(\mathrm{Cu}-\mathrm{N})$ stretching vibrations.

\subsubsection{UV-Vis Spectra}

In the visible region of the diffuse reflectance spectra of the complexes, an unsymmetrical absorption band at 590/595 $\mathrm{nm}$ with a shoulder at higher wavenumbers $(685 / 670 \mathrm{~nm}) \mathrm{can}$ be noticed (Supplementary Figures S5 and S6). This aspect is characteristic of copper(II) ions in a distorted square pyramidal stereochemistry [31]. As a result of coordination, the band assigned to intraligand $\pi \rightarrow \pi^{*}$ transitions for both ligands appears in the $260-340 \mathrm{~nm}$ range. 


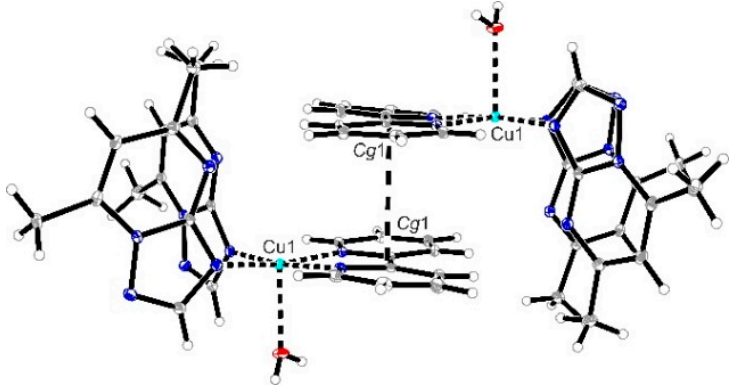

(a)

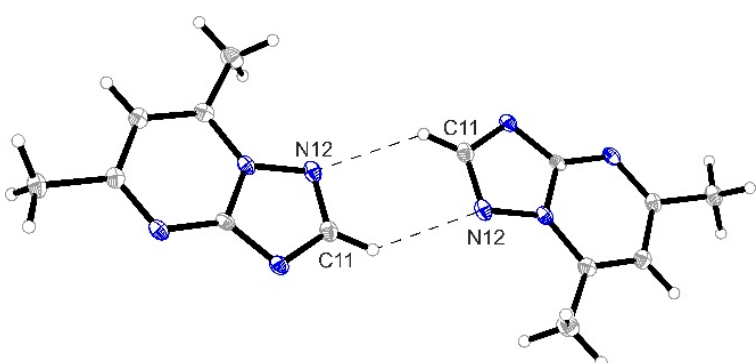

(b)

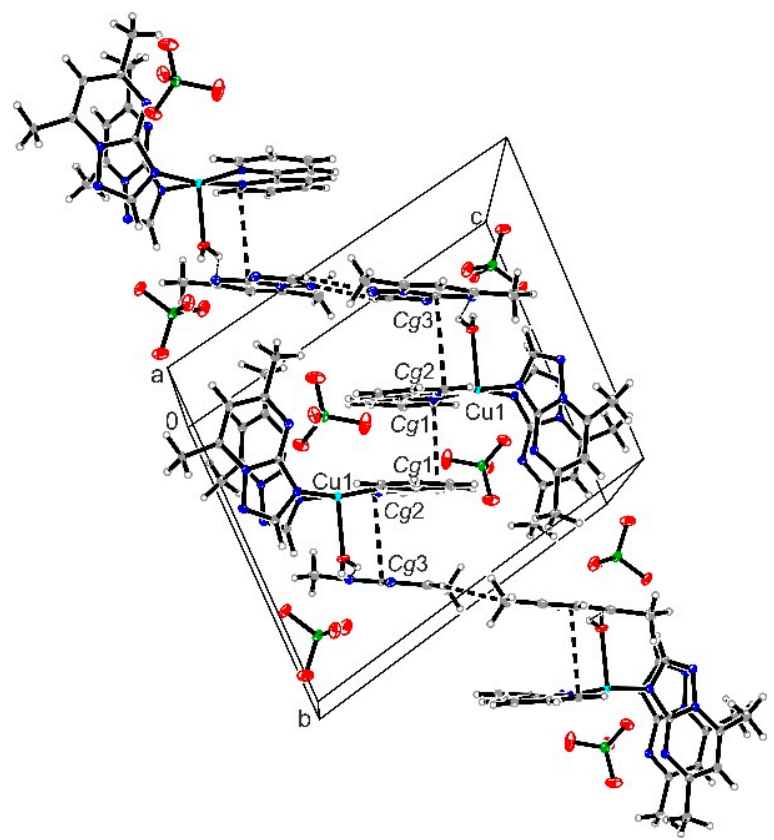

(c)

Figure 2. Dimer type formation between two cations of (1) through $\pi \cdots \pi$ interactions involving the bpy ligands (a); dimer type formation between two uncoordinated dmtp molecules involving $\mathrm{CH} \cdots \mathrm{N}$ interactions (b) and excerpt of the packing diagram of (1) presenting the formation of linear chains along the $b$-axis trough $\pi \cdots \pi, \mathrm{CH} \cdots \mathrm{N}$ and $\mathrm{OH} \cdots \mathrm{N}$ interactions between the cations and the dmtp-free moieties (c).

\subsubsection{EPR Spectroscopy \\ Solid-State EPR Spectroscopy}

The EPR spectra obtained in the bc crystal plane at X- and Q-band and room temperature are shown in Figure 3. A single Lorentzian-shaped resonance line, characteristic of a strong exchange, was observed for a magnetic field orientation at 0 and $180^{\circ}$ at both microwave frequencies, which is in good agreement with the results regarding the structure of the complexes where the $\mathrm{Cu}(\mathrm{II})$ is located in the basal plane of a square pyramid stereochemistry. In contrast, spectra with a resolved hyperfine structure, typical of weak exchange, were obtained for field orientations in the range of 20 to $160^{\circ}$. The g tensor for both complexes was an axial one with $\mathrm{g}_{\|}=2.24$ and $\mathrm{g}_{\perp}=2.06$ for complex (1) and $\mathrm{g}_{\|}=2.25$ and $\mathrm{g}_{\perp}=2.057$ for complex (2). The hyperfine coupling constants $\mathrm{A}_{\|}=16.7 \mathrm{mT}$ for complex (1) and $\mathrm{A}_{\|}=14 \mathrm{mT}$ for complex (2), respectively, were obtained. These values are in excellent agreement with those reported in the literature for $\mathrm{Cu}(\mathrm{II})$ in an axial distorted symmetry, such as the square pyramidal one [32]. 

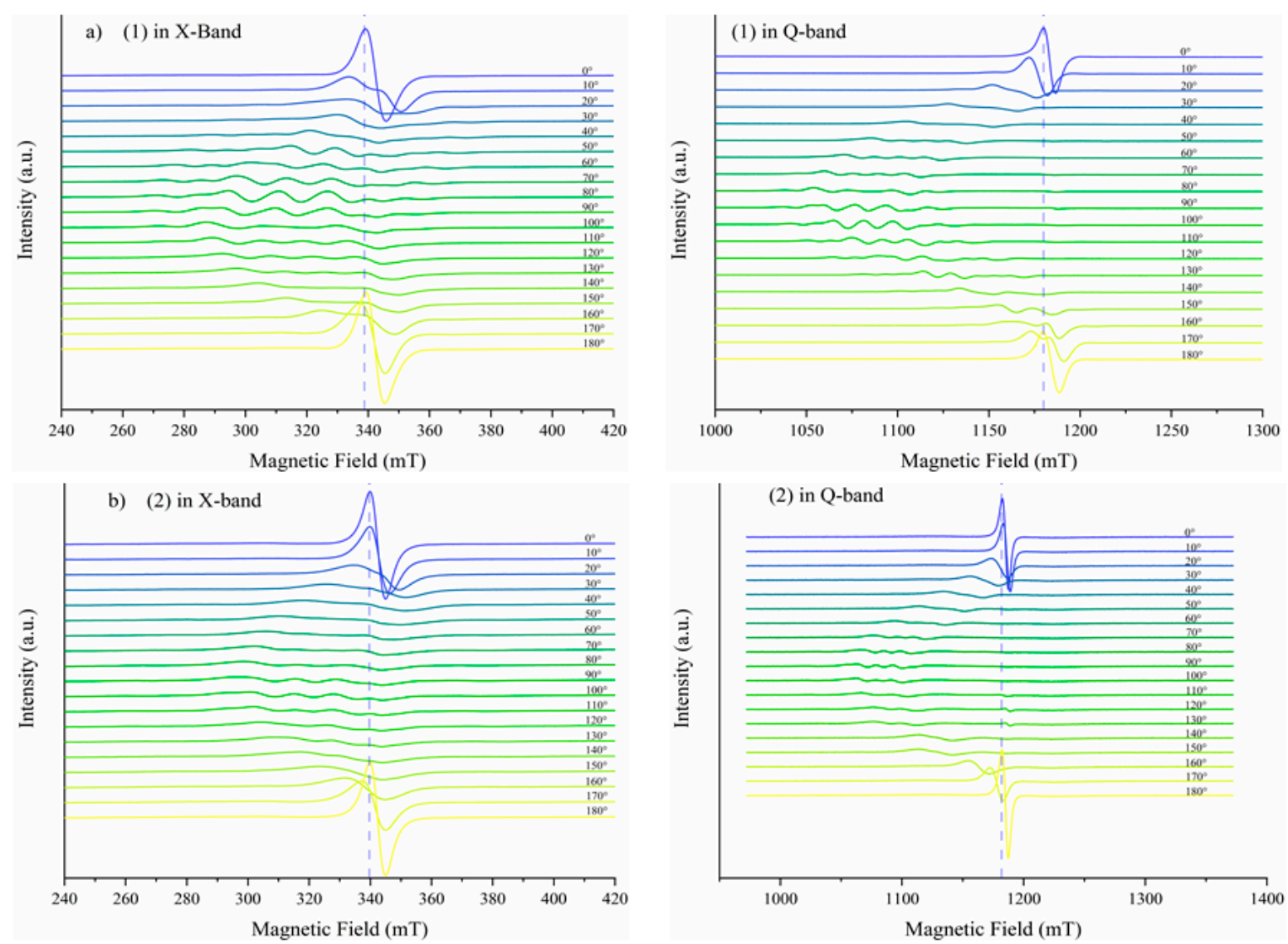

Figure 3. EPR spectra in $X$ and Q-band with rotation along the main magnetic field of complex (1) (a) and complex (2) (b).

\section{Solution EPR Spectroscopy}

In order to determine their biological activity, the complexes were solubilized in dimethyl-sulfoxide (DMSO); therefore, their stability in this solvent was evaluated using EPR spectroscopy. For this purpose, the intensity and line shape of the EPR signal of $5 \mathrm{mM}$ complex solutions were monitored over one week. As shown in Figure 4, no significant changes occurred after this period, indicating that the complexes are stable in DMSO.

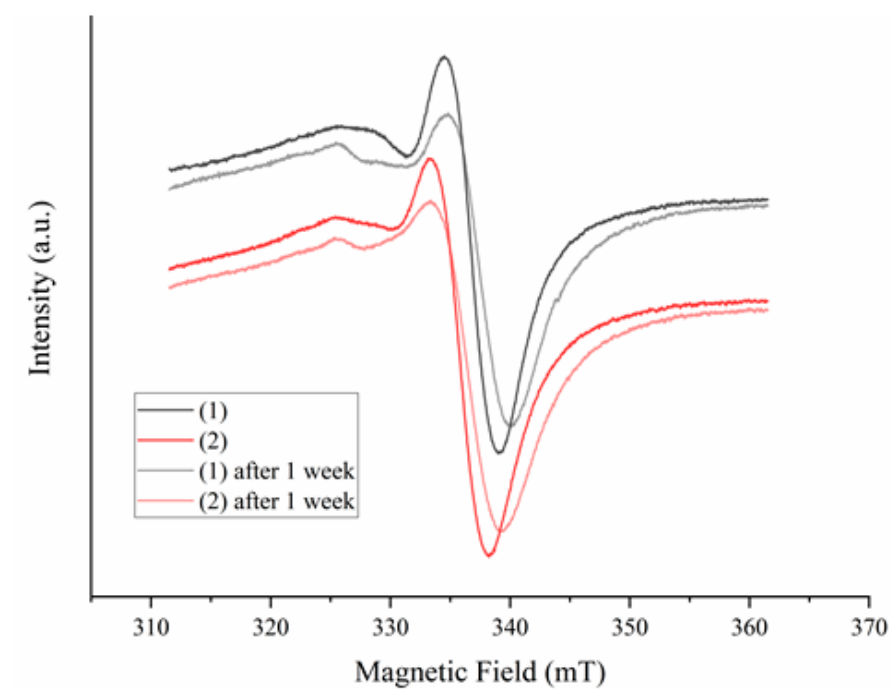

Figure 4. EPR spectra of complexes (1) and (2) in DMSO freshly prepared and after one week. 


\section{Voltammetric Studies}

The redox properties of the complexes were studied by cyclic voltammetry in order to obtain information concerning their oxidation potential, an important parameter that accounts for their interactions with redox active species in biological systems. The results were collected over two successive cycles in the anodic $+0.15-+0.9$ and, respectively, cathodic $+0.9--1.2 \mathrm{~V}$, potential ranges at a $0.05 \mathrm{~V} / \mathrm{s}$ scan rate were compared with those obtained for $\left[\mathrm{Cu}(\mathrm{DMSO})_{6}\right]\left(\mathrm{ClO}_{4}\right)_{2}$ under the same conditions (Table 3).

Table 3. Cyclic voltammetry data for complexes (1), (2) and $\left[\mathrm{Cu}(\mathrm{DMSO})_{6}\right]\left(\mathrm{ClO}_{4}\right)_{2}$.

\begin{tabular}{cccccc}
\hline Complex & $\mathrm{E}_{\mathbf{p a} 1}(\mathrm{~V})$ & $\mathrm{E}_{\mathbf{p c} 1}(\mathrm{~V})$ & $\mathrm{E}_{\mathbf{p c} 2}(\mathrm{~V})$ & $\mathrm{E}_{\mathbf{p c} 3}(\mathrm{~V})$ & $\begin{array}{c}\mathrm{E}_{1 / 2}(\mathrm{~V})^{\mathbf{a}} \\
(\mathbf{C u}(\mathrm{III}) / \mathbf{C u}(\mathrm{II}))\end{array}$ \\
\hline$\left[\mathrm{Cu}(\mathrm{DMSO})_{6}\right]\left(\mathrm{ClO}_{4}\right)_{\mathbf{2}}$ & +0.431 & +0.119 & & & \\
$(\mathbf{1})$ & +0.372 & +0.200 & +0.009 & -0.495 & +0.286 \\
$\mathbf{( 2 )}$ & +0.412 & +0.150 & +0.120 & -0.700 & +0.281 \\
\hline
\end{tabular}

${ }^{a}$ Half-wave reduction potentials were calculating using $\mathrm{E}_{1 / 2}=\left(\mathrm{E}_{\mathrm{pa} 1}+\mathrm{E}_{\mathrm{pc} 1}\right) / 2$.

The voltammograms for complexes (1) and (2) (Figure 5) display in the first cycle an oxidation step at $\sim+0.400 \mathrm{~V}$ assigned to $\mathrm{Cu}$ (II) to $\mathrm{Cu}$ (III) oxidation at $\mathrm{E}_{\mathrm{pa} 1}$ and three reduction waves corresponding to the sequences $\mathrm{Cu}(\mathrm{III}) / \mathrm{Cu}(\mathrm{II})$ at $\mathrm{E}_{\mathrm{pc} 1}, \mathrm{Cu}(\mathrm{II}) / \mathrm{Cu}(\mathrm{I})$ at $\mathrm{E}_{\mathrm{pc} 2}$ and $\mathrm{Cu}(\mathrm{I}) / \mathrm{Cu}(0)$ at $\mathrm{E}_{\mathrm{pc} 3}$, respectively (Table 3). The presence of these waves indicates that the organic ligands induce a higher stability of the $\mathrm{Cu}(\mathrm{III})$ and $\mathrm{Cu}(\mathrm{I})$ species in complexes (1) and (2) in comparison with $\left[\mathrm{Cu}(\mathrm{DMSO})_{6}\right]\left(\mathrm{ClO}_{4}\right)_{2}$.

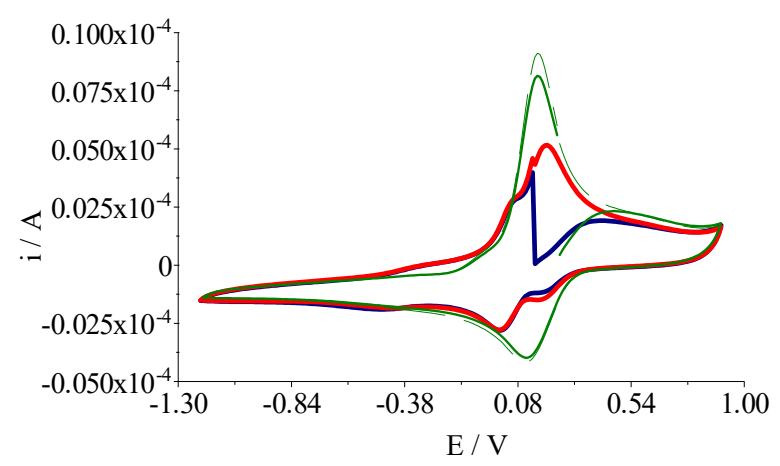

(a)

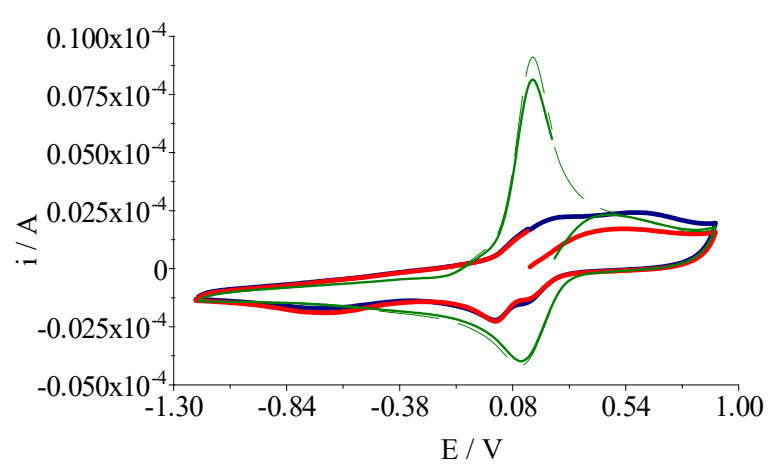

(b)

Figure 5. Cyclic voltammograms of complex (1) (a) and complex (2) (b), first cycle (blue line), second cycle (red line), cyclic voltamamograms of $\left[\mathrm{Cu}(\mathrm{DMSO})_{6}\right]\left(\mathrm{ClO}_{4}\right)_{2}$ (green line—first cycle and dashed green line—second cycle) in DMSO, $(0.1 \mathrm{M}$ $\mathrm{Bu}_{4} \mathrm{NClO}_{4}$; scan rate: $0.050 \mathrm{~V} / \mathrm{s}, 0.3 \mathrm{mM}$, working electrode: platinum disk, reference electrode: $\mathrm{Ag} / \mathrm{AgCl}\left(0.1 \mathrm{M} \mathrm{Bu}_{4} \mathrm{NClO}_{4}\right.$ in DMSO).

The second cycle of the voltammograms shows the same peaks on the cathodic part and a single large one accompanied by a prepeak. In the case of complex (2) it is observed that all values corresponding to reduction processes are shifted to more negative values.

The value of the half-wave potentials versus $\mathrm{Ag} / \mathrm{AgCl}\left(0.1 \mathrm{M} \mathrm{Bu}_{4} \mathrm{NClO}_{4}\right.$ solution in DMSO) indicates values of $\mathrm{Cu}$ (III) $/ \mathrm{Cu}$ (II) redox coupling included in the $+0.3-+0.9 \mathrm{~V}$ range, a proper potential for hydrogen peroxide reduction by copper complexes [33].

\subsection{Biological Characterization}

\subsubsection{Cell Viability and Lactate Dehydrogenase Assays}

Chemotherapy for melanoma that cannot be removed by surgery includes the use of some organic drugs like dacarbazine, cobimetinib fumarate, and trametinib, alone or in as a combined treatment [34]. However, their use is accompanied by severe side effects, including an increased risk of infection as well as resistance development. As a result, there 
is a continuous search for new antitumor drugs with reduced side effects and lower toxicity. $\mathrm{The} \mathrm{Cu}(\mathrm{II})$ systems represent beneficial species from this point of view, considering their reduced systemic toxicity [16]. Thus, several $\mathrm{Cu}$ (II) complexes were studied and proved to be as effective for melanoma treatment $[18,29,35-43]$ — some having, in addition, low toxicity on normal cells $[18,29,39-43]$.

In order to assess cellular viability, the complexes and the dmtp ligand were tested against the B16 murine melanoma cell line, and data were compared with those obtained in the BJ normal cell line. The results for compound (1) reported in Figure 5A show that BJ cells were not affected over the range of tested concentrations, independent of the duration of the treatment. However, compound (1) reduced the viability of B16 cells-the effect being proportional with the tested concentration, both at $24 \mathrm{~h}$ and $48 \mathrm{~h}$. The half-maximal inhibitory concentration $\left(\mathrm{IC}_{50}\right)$ of compound $(\mathbf{1})$ was $5.76 \mu \mathrm{g} / \mathrm{mL}(6.50 \mu \mathrm{M})$ at $24 \mathrm{~h}$ and $3.9 \mu \mathrm{g} / \mathrm{mL}(4.42 \mu \mathrm{M})$ at $48 \mathrm{~h}$ (Table 4). The results for compound (2) (Figure 5B) indicate that $\mathrm{BJ}$ cells treated for $24 \mathrm{~h}$ are affected by the compound, reducing their viability at the highest concentration by up to $45 \%$, while for $48 \mathrm{~h}$ by up to $10 \%$. The $\mathrm{IC}_{50}$ values obtained were $13.61 \mu \mathrm{g} / \mathrm{mL}(15.04 \mu \mathrm{M})$ for $24 \mathrm{~h}$ treatment and $4.5 \mu \mathrm{g} / \mathrm{mL}(4.97 \mu \mathrm{M})$ for $48 \mathrm{~h}$, respectively (Table 4). For B16 cells, when treated with (2), the cell viability decreased to $5 \%$, with $\mathrm{IC}_{50}$ values of $6.88 \mu \mathrm{g} / \mathrm{mL}(7.6 \mu \mathrm{M})$ after $24 \mathrm{~h}$ treatment and $4.15 \mu \mathrm{g} / \mathrm{mL}(4.58 \mu \mathrm{M})$ after $48 \mathrm{~h}$, respectively (Table 3 ). The ligand dmtp did not affect the viability of either BJ or B16 cells at 24 or $48 \mathrm{~h}$.

Table 4. The half-maximal inhibitory concentration $\left(\mathrm{IC}_{50}\right)$ and therapeutic index (TI) of compounds (1), (2), and dmtp.

\begin{tabular}{|c|c|c|c|c|c|c|}
\hline \multirow{3}{*}{ Compound } & \multicolumn{4}{|c|}{$\mathrm{IC}_{50}(\mu \mathrm{g} / \mathrm{mL} ; \mu \mathrm{M})$} & \multirow{2}{*}{\multicolumn{2}{|c|}{ TI }} \\
\hline & \multicolumn{2}{|c|}{ BJ } & \multicolumn{2}{|c|}{ B16 } & & \\
\hline & $24 \mathrm{~h}$ & $48 \mathrm{~h}$ & $24 \mathrm{~h}$ & $48 \mathrm{~h}$ & $24 \mathrm{~h}$ & $48 \mathrm{~h}$ \\
\hline dmtp & $\mathrm{ND}$ * & ND & ND & ND & & \\
\hline (1) & ND & ND & $5.76 ; 6.50$ & $3.90 ; 4.42$ & 8.68 & 12.82 \\
\hline (2) & $13.61 ; 15.04$ & $4.50 ; 4.97$ & $6.88 ; 7.60$ & $4.15 ; 4.58$ & 1.98 & 1.08 \\
\hline
\end{tabular}

${ }^{*} \mathrm{ND}-$ not determined.

It is worth mentioning that for other copper compounds tested on melanoma cells, the reported $\mathrm{IC}_{50}$ values were similar [35-43], and only one study reported lower values [38] compared with those found for complex (1).

A summary of $\mathrm{IC}_{50}$ data recorded at $48 \mathrm{~h}$ for B16 cells and TI values for perchlorate $\mathrm{Cu}$ (II) complexes with N-N [29] and tpds (dmtp and pmtp [18]) ligands is presented in Table 5. An improved activity of complex (1) in comparison with similar species bearing bpy and bpy/pmtp ligands was confirmed by the lowest value of $4.42 \mu \mathrm{M}$ of $\mathrm{IC}_{50}$.

Table 5. The $\mathrm{IC}_{50}(\mu \mathrm{M})$ and $\mathrm{TI}$ values for perchlorate $\mathrm{Cu}(\mathrm{II})$ complexes with $\mathrm{N}-\mathrm{N}$ and tpds ligands.

\begin{tabular}{ccccccc}
\hline Compound & $\mathbf{( 1 )}$ & CubP & CubPP & (2) & CupP & CupPP \\
\hline IC $_{50}(\mu \mathrm{M})$ & 4.42 & 16 & 20 & 4.58 & 3.70 & 4.00 \\
TI & 12.82 & 5.53 & 3.23 & 1.08 & 0.80 & 0.88 \\
Reference & & {$[29]$} & {$[18]$} & & {$[29]$} & {$[18]$} \\
\hline
\end{tabular}

$\mathrm{CubP},\left\{\left[\mathrm{Cu}(\text { bpy })_{2}\left(\mu_{2} \mathrm{OClO}_{3}\right)\right] \mathrm{ClO}_{4}\right\}_{\mathrm{n}} ; \mathrm{CubPP},\left[\mathrm{Cu}(\text { bpy })_{2}(\right.$ pmtp $\left.)\right]\left(\mathrm{ClO}_{4}\right)_{2} \mathrm{CupP},\left[\mathrm{Cu}(\text { phen })_{2}\left(\mathrm{OH}_{2}\right)\right]\left(\mathrm{ClO}_{4}\right)_{2} ; \mathrm{CupPP}$, $\left[\mathrm{Cu}(\text { phen })_{2}(\right.$ pmtp $\left.)\right]\left(\mathrm{ClO}_{4}\right)_{2}$.

Based on the $\mathrm{IC}_{50}$ reported in Table 3, the therapeutic index (TI) was calculated; a higher TI value indicates a better cell selectivity. When no toxicity was detected at the highest concentration achieved in our experiments, a value two times higher was used for this calculation. Thus, from these data, it can be seen that compound (1) proved to be the most efficient against cancer cells, with a TI of 8.68 after $24 \mathrm{~h}$ and 12.82 at $48 \mathrm{~h}$. For compound (2), the TI was 1.98 at $24 \mathrm{~h}$ and 1.08 at $48 \mathrm{~h}$, respectively. 
As a comparison, the TI values suggested a better activity of bpy derivatives in comparison with phen ones, and for dmtp species in comparison with pmtp. This could be related to a lower molar weight that allows an enhanced solubility, and also to the less bulky substituents that allow better interactions with the cellular targets.

To determine if the compounds affect membrane integrity, the lactate dehydrogenase (LDH) was evaluated at $24 \mathrm{~h}$ and $48 \mathrm{~h}$ (Figure 6D-F). Compound (1) did not affect the membrane integrity independent of the tested conditions (Figure 6D). When BJ cells were treated with compound (2) for $24 \mathrm{~h}$, the membrane integrity was not affected (Figure 6E). However, at $48 \mathrm{~h}$, compound (2) induced an $\mathrm{LDH}$ release of around $20 \%$. As for the B16 cells, compound (2) induced a 60\% LDH release at $24 \mathrm{~h}$ and 100\% LDH release at $48 \mathrm{~h}$. These results indicate that compound (2) slightly affects the membrane integrity of BJ cells with increasing time and concentration. However, the effect is more severe for B16 tumoral cells. Similar to compound (1), dmtp did not affect the membrane integrity of the cells (Figure 6F).
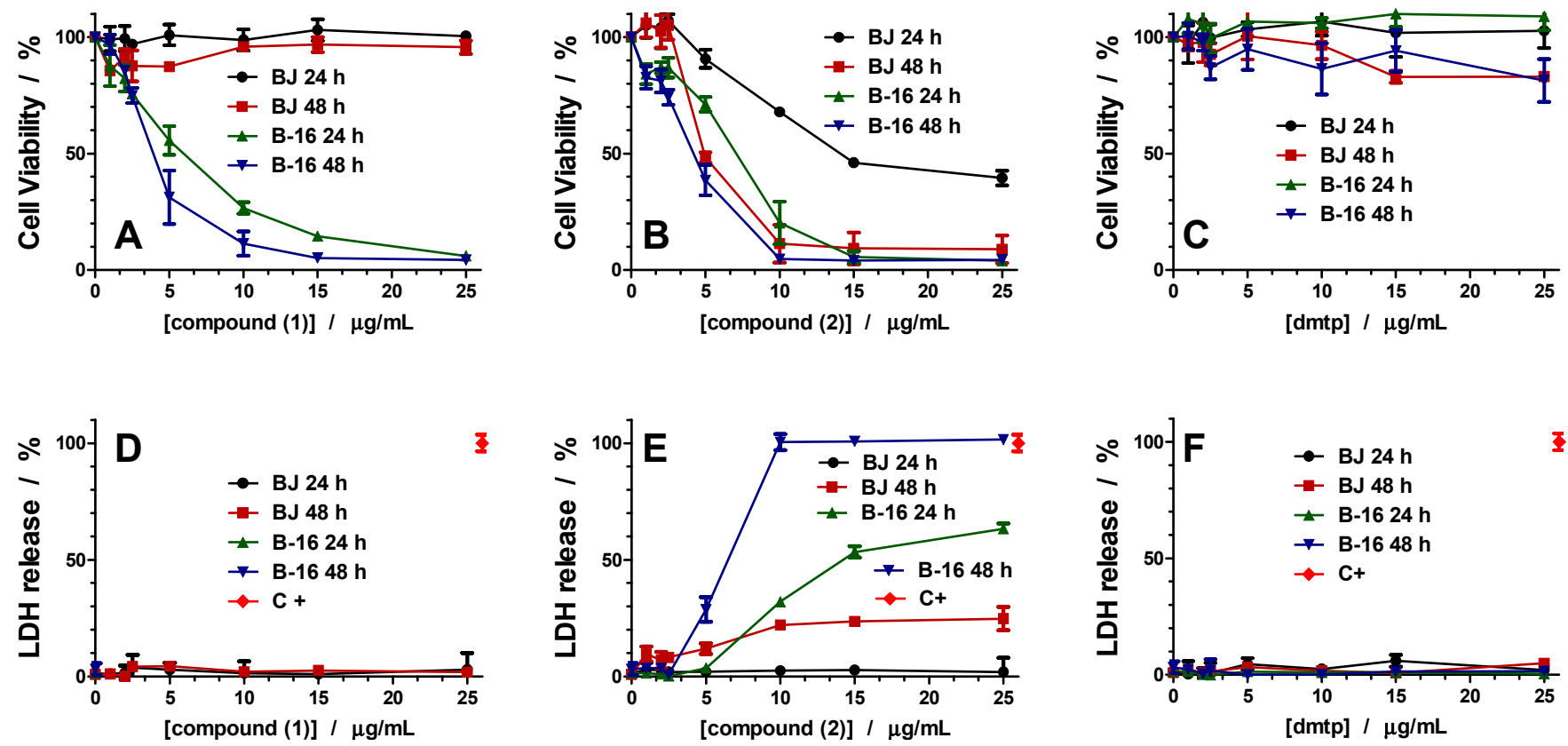

Figure 6. Cellular viability (A-C) and LDH release (D-F) of complexes (1), (2), and dmtp against BJ and B16 cells after 24 and $48 \mathrm{~h}$.

\subsubsection{Cell Morphology}

The morphological changes induced by the treatment of the BJ and B16 cell lines with the tested compounds at two different concentrations (2.5 and $10 \mu \mathrm{g} / \mathrm{mL})$ applied for $24 \mathrm{~h}$ were investigated by fluorescence microscopy.

In BJ cells, dmtp at both concentrations $(2.5 \mu \mathrm{g} / \mathrm{mL} / 16.89 \mu \mathrm{M}$ and $10 \mu \mathrm{g} / \mathrm{mL} / 67.56 \mu \mathrm{M})$ did not alter their morphology (Figure 7B,E) compared with the control (Figure 6A). Similarly, no effect was observed for concentrations of 2.5 or $10 \mu \mathrm{g} / \mathrm{mL}(2.84$ or $11.35 \mu \mathrm{M})$ in the case of compound (1) (Figure 7C,F). In the case of (2), only a concentration of $10 \mu \mathrm{g} / \mathrm{mL}(11.05 \mu \mathrm{M})$ affected the cellular morphology, by altering the cellular cytoskeleton (Figure 7G).

The morphology of B16 cells treated by dmtp, (1) and (2) for $24 \mathrm{~h}$ is not altered at a concentration of $2.84 \mu \mathrm{M}$ and $2.76 \mu \mathrm{M}$, respectively (Figure 7) as compared with the control. In contrast, at a concentration of $10 \mu \mathrm{g} / \mathrm{mL}(11.05 \mu \mathrm{M})$, significant changes are observed for complex (2) (Figure 7N). 


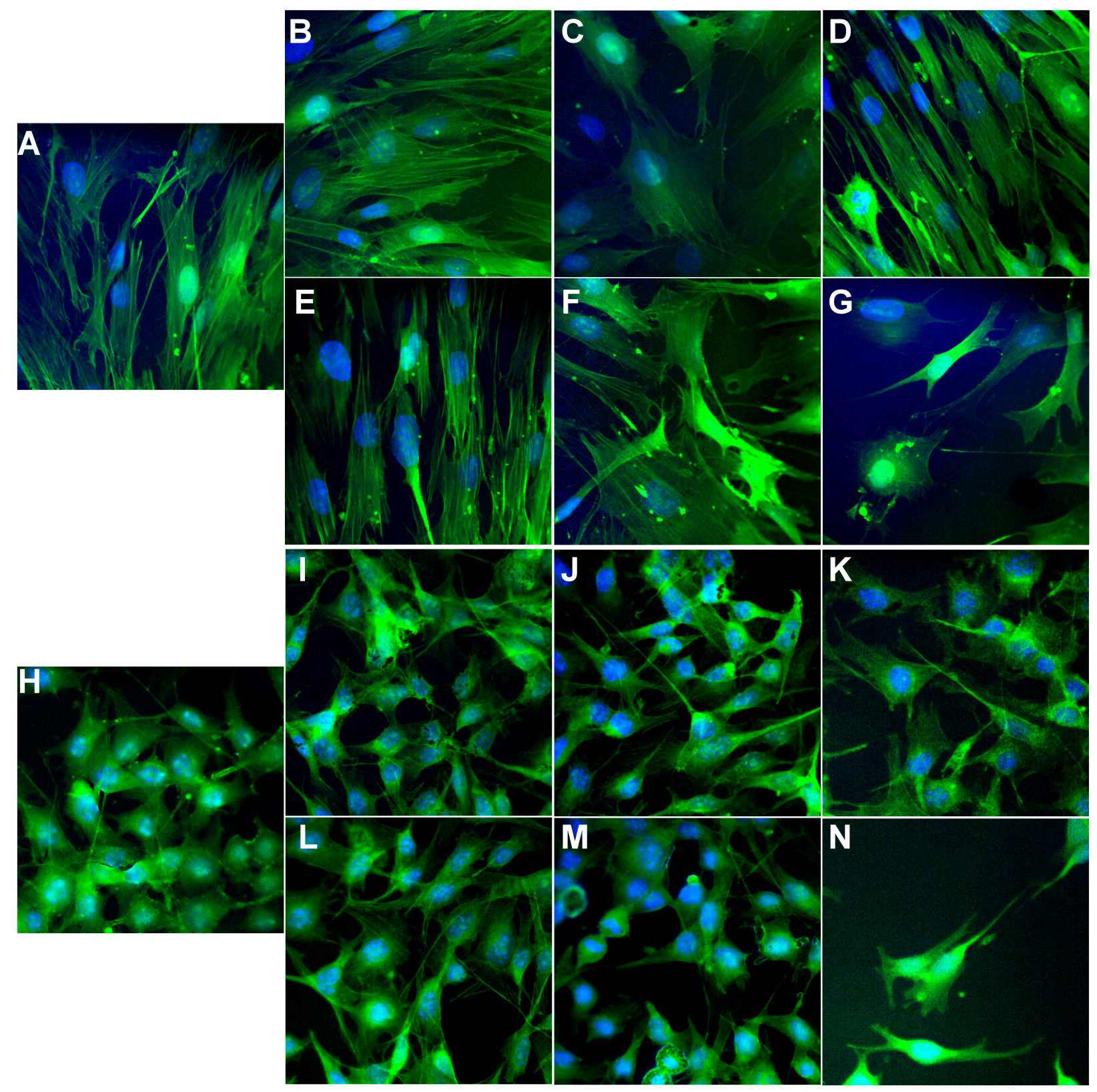

Figure 7. Fluorescence microscopy images recording morphological changes of cytoskeleton (BJ cells: control cells (A), treated with $2.5 \mu \mathrm{g} / \mathrm{mL} / 16.89 \mu \mathrm{M}(\mathbf{B})$ and $10 \mu \mathrm{g} / \mathrm{mL} / 67.57 \mu \mathrm{M}(\mathbf{E}) \mathrm{dmtp}, 2.5 \mu \mathrm{g} / \mathrm{mL} / 2.83 \mu \mathrm{M}(\mathbf{C})$ and $10 \mu \mathrm{g} / \mathrm{mL} / 11.35 \mu \mathrm{M}$ (F) compound (1) and $2.5 \mu \mathrm{g} / \mathrm{mL} / 2.76 \mu \mathrm{M}$ (D) and $10 \mu \mathrm{g} / \mathrm{mL} / 11.05 \mu \mathrm{M}$ (G) compound (2) for $24 \mathrm{~h}$; B16 cells: control cells $(\mathbf{H})$, treated with $2.5 \mu \mathrm{g} / \mathrm{mL} / 16.89 \mu \mathrm{M}(\mathbf{I})$ and $10 \mu \mathrm{g} / \mathrm{mL} / 67.57 \mu \mathrm{M}(\mathbf{L}) \mathrm{dmtp}, 2.5 \mu \mathrm{g} / \mathrm{mL} / 2.83 \mu \mathrm{M}(\mathrm{J})$ and $10 \mu \mathrm{g} / \mathrm{mL} / 11.35 \mu \mathrm{M}(\mathbf{M})$ compound (1) and $2.5 \mu \mathrm{g} / \mathrm{mL} / 2.76 \mu \mathrm{M}(\mathbf{K})$ and $10 \mu \mathrm{g} / \mathrm{mL} / 11.05 \mu \mathrm{M}$ (N) compound (2) for $24 \mathrm{~h}$ ).

\subsubsection{Microbiological Assay}

Usually, tumor development produces an immunosuppressive effect and gut microbiota dysbiosis, and thus, the development of infections associated with opportunistic microorganisms is favored. Thus, it is essential for compounds with antitumor activity to also possess an antimicrobial potential directed towards pathogenic species. As a result, the antimicrobial activity of complexes (1) and (2) was evaluated against Gram-negative (E. coli 25922, P. aeruginosa ATCC 27853) and Gram-positive (S. aureus ATCC 25853, MRSA 388) bacteria, frequently isolated from cancer patient infections.

The results showed that the compounds exhibited a more potent antimicrobial effect against the Gram-positive bacteria, enhanced in comparison with that of dmtp. Complex 
(2) exhibited the best antibacterial activity, with minimal inhibitory concentration (MIC) values ranging from 0.34 to $0.02 \mathrm{mM}$ (Table 6). It is noteworthy that complex (2) exhibited strong antimicrobial activity against MRSA 388. MRSA has been mentioned in the EU/EEA (EARS-Net) Annual Epidemiological Report for 2019 as one of the most common causes of bloodstream infections, exhibiting a high burden in terms of morbidity and mortality [44]. These strains have become a severe clinical and epidemiological problem, as resistance to methicillin implies resistance to all $\beta$-lactam antibiotics [45].

Table 6. The MIC values (mM) for ligands and complexes.

\begin{tabular}{cccc}
\hline Bacterial Strain & dmtp & (1) & (2) \\
\hline E. coli 25922 & 8.45 & 0.71 & 0.34 \\
P. aeruginosa 27853 & 8.45 & 0.71 & 0.69 \\
S. aureus 25923 & 8.45 & 0.18 & 0.04 \\
MRSA 388 & 16.90 & 0.35 & 0.02 \\
\hline
\end{tabular}

The violet crystal quantification of biofilm formed on polystyrene surfaces in the presence of different concentrations of the complexes showed that both compounds were able to inhibit biofilm formation at the initial stage by reducing the expression of adhesion proteins, with the minimal biofilm eradication concentration (MBEC) values ranging from 0.71 to $0.04 \mathrm{mM}$ (Table 7). The strongest antibiofilm effects were noticed against Gram-positive bacteria, including the MRSA strain. Methicillin resistance plays a crucial role in staphylococcal biofilm development, primarily mediated by the production of eDNA and cell surface adhesion proteins. Previous reports showed that $\mathrm{Cu}$ (II) complexes exhibit strong antimicrobial activity against both MRSA and methicillin-susceptible Staphylococcus aureus (MSSA) clinical isolates of both human and animal origin. It is not only effective in killing planktonic cells, but also has antimicrobial activity against biofilm and intracellular bacterial cells [46], therefore being a promising lead for the development of novel therapeutic strategies for persistent bacterial infections [47].

Table 7. The compounds' influence on biofilm formation (MBEC value; $\mathrm{mM}$ ).

\begin{tabular}{cccc}
\hline Bacterial Strain & dmtp & $\mathbf{( 1 )}$ & (2) \\
\hline E. coli 25922 & 8.45 & 0.71 & 0.17 \\
P. aeruginosa 27853 & 8.45 & 0.71 & 0.69 \\
S. aureus 25923 & 8.45 & 0.18 & 0.04 \\
MRSA 388 & 16.90 & 0.35 & 0.04 \\
\hline
\end{tabular}

A comparison of MIC and MBEC data for perchlorate $\mathrm{Cu}(\mathrm{II})$ complexes with N-N and tp derivatives (dmtp and pmtp) ligands is presented in Tables 8 and 9. From these data it can be concluded that the optimal activity of compound (1) (MIC of $0.18 \mathrm{mM}$ ) was observed in the case of the $S$. aureus strain, and for compound (2) in the case of the MRSA strain (MIC of $0.02 \mathrm{mM}$ ). Concerning the anti-biofilm activity, only complex (2) exhibited improved activity compared to similar species in interactions with the MRSA strain, as revealed by the MBEC value of $0.04 \mathrm{mM}$.

Table 8. The MIC values (mM) for perchlorate $\mathrm{Cu}(\mathrm{II})$ complexes with $\mathrm{N}-\mathrm{N}$ and tpds ligands.

\begin{tabular}{ccccccc}
\hline Bacterial Strain & $\mathbf{( 1 )}$ & CubP & CubPP & (2) & CupP & CupPP \\
\hline E. coli 25922 & 0.71 & 0.54 & 0.20 & 0.34 & 0.03 & 0.02 \\
P. aeruginosa 27853 & 0.71 & 1.09 & 0.40 & 0.69 & 0.50 & 0.09 \\
S. aureus 25923 & 0.18 & 0.27 & 0.40 & 0.04 & 0.03 & 0.01 \\
MRSA 388 & 0.35 & 0.27 & 0.40 & 0.02 & 0.12 & 0.05 \\
\hline
\end{tabular}


Table 9. The $\mathrm{Cu}(\mathrm{II})$ complexes with $\mathrm{N}-\mathrm{N}$ and tpds' influence on biofilm formation (MBEC value; $\mathrm{mM}$ ).

\begin{tabular}{ccccccc}
\hline Bacterial Strain & $\mathbf{( 1 )}$ & CubP & CubPP & (2) & CupP & CupPP \\
\hline E. coli 25922 & 0.71 & 0.54 & 0.40 & 0.17 & 0.10 & 0.02 \\
P. aeruginosa 27853 & 0.71 & 1.09 & 0.40 & 0.69 & 0.50 & 0.09 \\
S. aureus 25923 & 0.18 & 0.14 & 0.80 & 0.04 & 0.03 & 0.01 \\
MRSA 388 & 0.35 & 0.27 & 0.40 & 0.04 & 0.10 & 0.05 \\
\hline
\end{tabular}

\subsection{Complexes' Interactions with ROS and DNA}

The $\mathrm{Cu}(\mathrm{II})$ complexes' interactions with DNA are complex and usually involve its degradation through reactive oxygen species (ROS) generated in Fenton-like reactions [33]. This interaction is favored when the ligands exhibit the ability to intercalate into the DNA strands. As a result, the complexes' interactions with ROS and DNA were studied in order to propose a possible mechanism of action.

\subsubsection{Superoxide Scavenging Ability}

EPR spectroscopy was used to test the compounds' ability to scavenge or trap reactive oxygen species. Figure 8 shows the EPR signal evolution as a function of the concentration of $\mathrm{O}_{2}{ }^{-}$and $\mathrm{H}_{2} \mathrm{O}_{2}$ species added to a $5 \mathrm{mM}$ DMSO complex solution. $\mathrm{KO}_{2}$ is highly reactive and was added in 10 and $50 \mu \mathrm{M}$ concentrations. Complex (2) showed some scavenging ability towards the $\mathrm{O}_{2}{ }^{-}$radicals, which was demonstrated by the decrease in the EPR signal intensity when adding $\mathrm{KO}_{2}$. When adding $\mathrm{H}_{2} \mathrm{O}_{2}$ as an $\mathrm{OH}$. radical source, the EPR signal remained unchanged, indicating no reaction towards the hydroxyl radicals. The intensity of the EPR spectra increased at both $\mathrm{KO}_{2}$ and $\mathrm{H}_{2} \mathrm{O}_{2}$, indicating that the superoxide species and hydroxyl radicals were trapped rather than scavenged by complex (1).
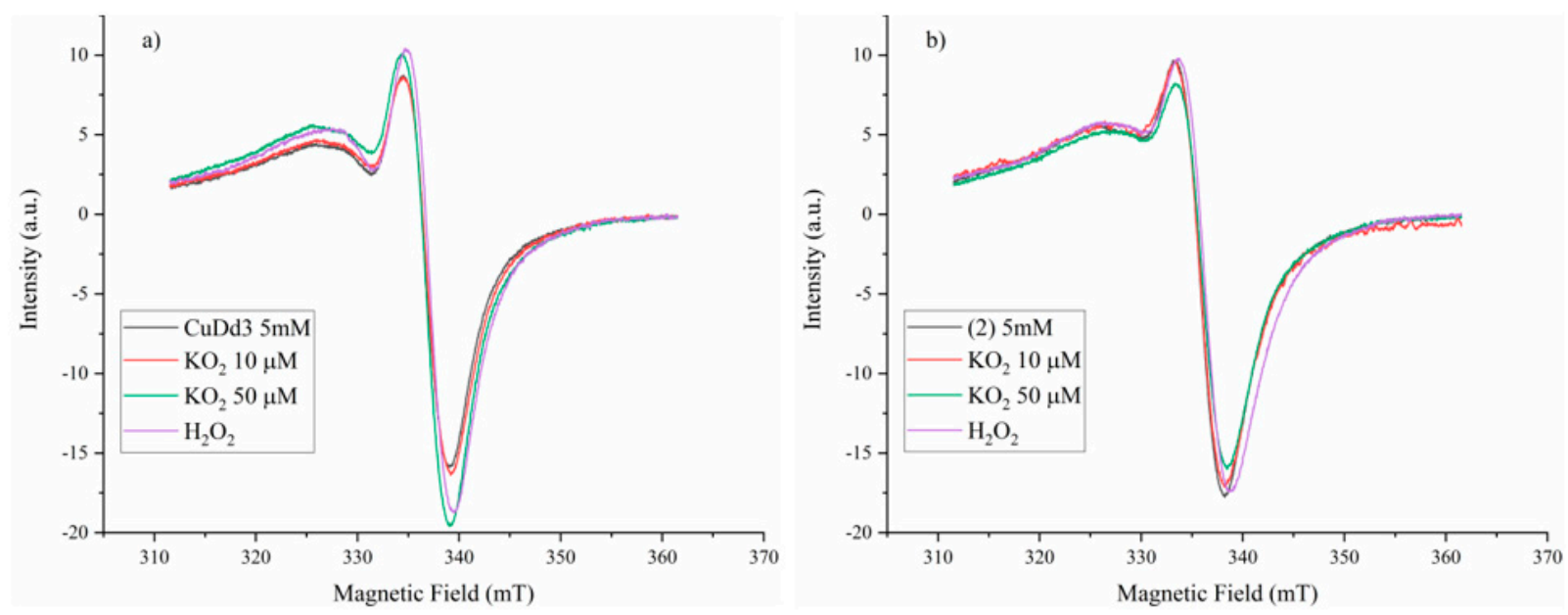

Figure 8. EPR spectra of complex (1) (a) and (2) (b) in interaction with $\mathrm{O}_{2}{ }^{-}$and $\mathrm{H}_{2} \mathrm{O}_{2}$.

\subsubsection{Effect of Compounds on Saccharomyces cerevisiae Cells}

As complexes (1) and particularly (2) exhibited some superoxide-scavenging activity, as seen by EPR spectroscopy (Figure 8), we checked if the two compounds had any protective action against the deleterious effect of superoxide ions in vivo. To check this possibility, compounds (1) and (2) were tested on Saccharomyces cerevisiae strains defective in cytosolic $\mathrm{Cu}, \mathrm{Zn}$-superoxide dismutase SOD1 (sod1 $\Delta$ strain) or mitochondrial Mn-superoxide dismutase SOD2 (sod $2 \Delta$ strain). Both $\operatorname{sod} 1 \Delta$ and $\operatorname{sod} 2 \Delta$ strains are sensitive to superoxidegenerating drugs, such as menadione or paraquat. We noted that the growth of yeast cells-both wild type (WT) and knockout strains $\operatorname{sod} 1 \Delta$ or $\operatorname{sod} 2 \Delta$-was not affected by exposure to compounds (1) and (2), and this apparent lack of toxicity was recorded for concentrations up to $2 \mathrm{mM}$ in the cell environment. Nevertheless, we noticed that both (1) and (2) alleviated the sensitivity of $\operatorname{sod} 1 \Delta$ and $\operatorname{sod} 2 \Delta$ to menadione (a superoxide-generating 
drug; Figure 8a), indicating that when present in non-toxic, physiologic concentrations, compounds (1) and (2) can act as superoxide scavengers in yeast cells devoid of regular SOD activity.

Deleting the SOD1 gene in yeast is accompanied by lysine auxotrophy, apparently caused by superoxide generation under aerobic conditions, affecting the metabolic pathway involved in lysine biosynthesis [48]. This phenotype affords a straightforward approach for testing the superoxide-scavenging traits of various chemicals $[49,50]$. We, therefore, tested whether our compounds alleviate lysine auxotrophy of $\operatorname{sod} 1 \Delta$ cells. We found indeed that (1), and to a higher extent (2), improved the growth of sod1 $\Delta$ mutants in SC-Lys medium (Figure 9b,c).

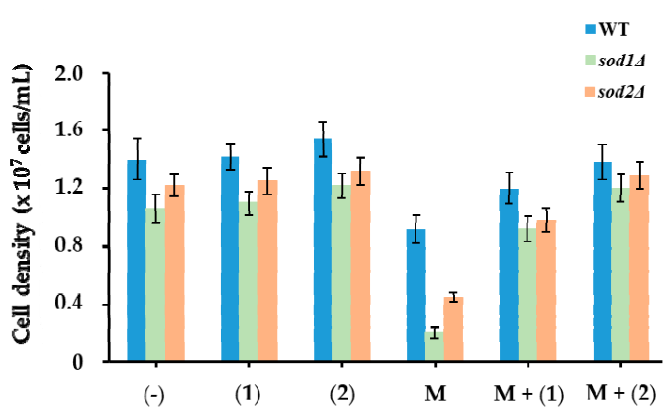

(a)

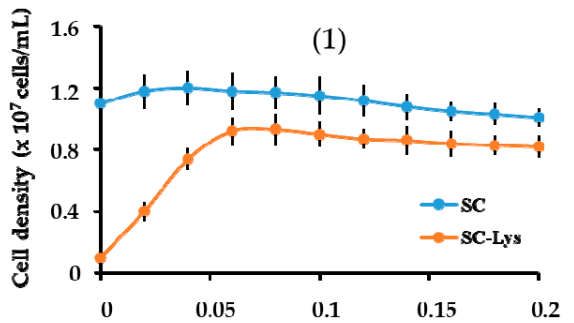

(b)

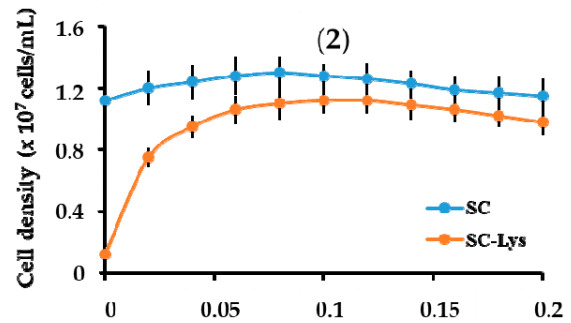

(c)

Figure 9. Effect of (1) and (2) on alleviating superoxide-related growth defects in Saccharomyces cerevisiae. Effect on cell growth in the presence of the superoxide-generating drug, menadione (a). Yeast cells were inoculated in SC $\left(10^{6}\right.$ cells $\left./ \mathrm{mL}\right)$, and their proliferation was determined spectrophotometrically $\left(\mathrm{OD}_{660}\right)$ after $16 \mathrm{~h}$ of exposure to $0.1 \mathrm{mM}$ of each of the indicated compounds. $\mathrm{M}$, menadione. Effect of compounds $(\mathbf{1}) /(\mathbf{b})$ and $(\mathbf{2}) /(\mathbf{c})$ on alleviating lysine auxotrophy of $\operatorname{sod} 1 \Delta$. Mid-log phase sod $1 \Delta$ cells suspended $\left(1 \times 10^{6}\right.$ cells $\left./ \mathrm{mL}\right)$ in SC or SC-Lys were grown for $16 \mathrm{~h}\left(30^{\circ} \mathrm{C}, 250 \mathrm{rpm}\right)$ in the presence of various concentrations of the complex before cell growth was determined spectrophotometrically $\left(\mathrm{OD}_{660}\right)$. Values are mean $\pm \mathrm{SD}$ of duplicate determinations of three biological replicates.

\subsubsection{DNA-Binding Properties of Compounds}

Complexes of (1) and (2) exhibited low toxicity against eukaryotic cells and even showed a protective effect against the deleterious action of superoxide ions (Figure 8). Despite their apparent low toxicity, we further investigated the interactions between complex (1) or (2) with DNA. The modifications induced by DNA to the spectral characteristics of the two complexes were determined through both absorption and fluorescence spectra modifications.

\section{Absorption Spectra}

Absorption spectroscopy is often used to monitor the interactions of a compound with DNA through band intensity modification, which generally indicates intercalative abilities [51]. The binding of complexes (1) and (2) to $\lambda$-DNA was determined by monitoring the absorption spectra of a fixed complex concentration $(5 \mu \mathrm{M})$, to which an increasing 
amount of DNA solution was added. The binding of complex (1) to $\lambda$-DNA led to a decrease in the absorption intensity of the band (Figure 9a), indicating possible intercalation of (1) into $\lambda$-DNA strands.

The binding of complex (2) to $\lambda$-DNA was also accompanied by a decrease in the absorption intensity of the spectral bands, with DNA concentrations increasing (Figure 10b). The hypochromism observed for the absorption band indicates that similarly to (1), complex (2) also binds to $\lambda$-DNA, probably by intercalation through the planar aromatic rings of the $\mathrm{N}-\mathrm{N}$-chelating ligands. Continuing to increase $\lambda$-DNA after reaching saturation was no longer accompanied by the hypochromic effect, and the spectra were not significantly different after reaching saturation.

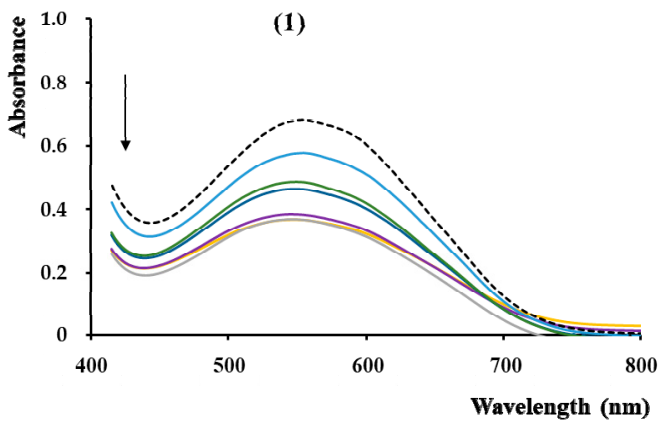

(a)

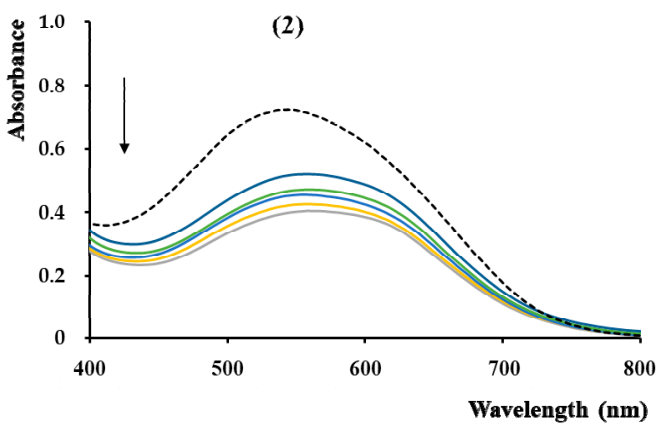

(b)

Figure 10. Absorption spectra of (1) (a) and (2) (b) in the absence of DNA (black, dotted line) or in Table 5. $\mu \mathrm{M}$ complex concentration.

Fluorescence Spectra

The capacity of (1) and (2) to quench the fluorescence of the $\lambda$-DNA/EB adduct was also determined. Ethidium bromide (EB) is one of the most utilized dyes for DNA detection as it causes intense fluorescence after intercalating into DNA [52]. We noticed that when adding increments of (1) and (2) to $\lambda$-DNA pre-treated with EB, the fluorescence intensity decreased-a clear indication that the complex competes with EB to the binding sites of DNA (Figure 11).

\subsubsection{Nuclease Activity}

To investigate the DNA cleavage activity of the two $\mathrm{Cu}(\mathrm{II})$ complexes, plasmidial DNA was incubated with (1) and (2), both in the absence or in the presence of activating agents, such as $\mathrm{H}_{2} \mathrm{O}_{2}$ or ascorbate. Exposure of DNA to the $\mathrm{Cu}$ (II) complexes in the presence of $\mathrm{H}_{2} \mathrm{O}_{2}$ exploits the CuII/III redox couple, while in the presence of ascorbate, the $\mathrm{CuI} / \mathrm{II}$ redox couple is exploited [53]. The nuclease activity of copper(II) complexes (1) and (2) was tested on plasmid pRSII325, which is a $6835 \mathrm{bp}$ (base pair) circular plasmid. Gel electrophoresis of purified pRSII325 identified two main bands belonging to the supercoiled (SC) plasmid, which migrates faster, and the nicked-circular (NC) plasmid, which migrates slower (Figure 12, lane 1).

It was noted that both ascorbate (Figure 12, lane 2) and $\mathrm{H}_{2} \mathrm{O}_{2}$ (Figure 12, lane 3) alone caused DNA relaxation to the NC form. Compounds (1) and (2) alone also caused plasmid relaxation to the NC form in a dose-dependent manner (Figure 12, lanes 4-7). Incubating pRSII325 with (1) in the presence of either ascorbate (Figure 12, lanes 8 and 9) or $\mathrm{H}_{2} \mathrm{O}_{2}$ (Figure 12, lanes 10 and 11) led to DNA degradation, indicating a strong nuclease activity-especially in the presence of $\mathrm{H}_{2} \mathrm{O}_{2}$. The nuclease activity of (2) followed a pattern similar to (1), with $\mathrm{H}_{2} \mathrm{O}_{2}$ strongly enhancing the nuclease activity, apparently irrespective of (2) concentration (Figure 12, lanes 14 and 15). Otherwise, the complexes' ability to interact with $\mathrm{H}_{2} \mathrm{O}_{2}$ was evidenced by EPR and cyclic voltammetry experiments. As in the case of (1), a higher concentration of (2) was needed for full nuclease activity enhanced by ascorbate (Figure 12, lanes 12 and 13). 


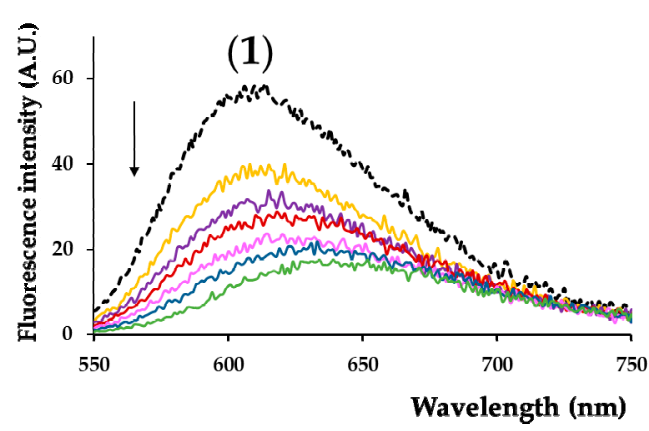

(a)

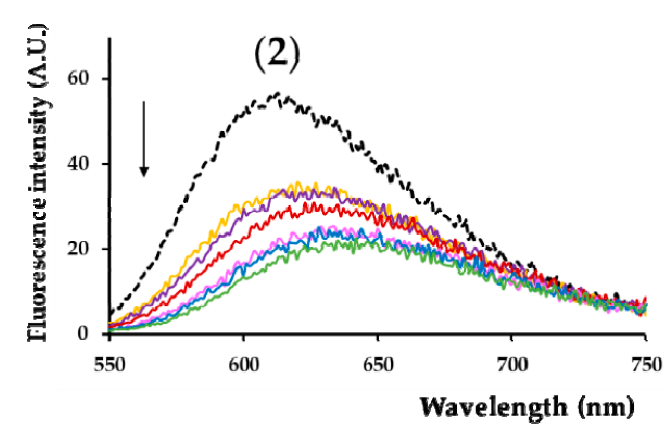

(b)

Figure 11. Emission spectra of $\lambda$-DNA/EB in Tris $/ \mathrm{HCl} / \mathrm{NaCl}$ buffer, $\mathrm{pH}=8$, in the absence (black curves) or the presence of increasing concentrations of (1) (a) and (2) (b). Arrows indicate the increase in [complex].

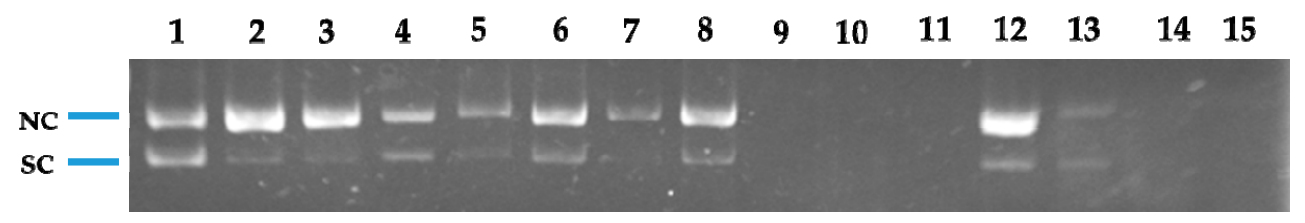

Figure 12. Gel electrophoresis image of pRSII425 (100 ng/ $\mu \mathrm{L})$ after incubation for $1 \mathrm{~h}$ at $37^{\circ} \mathrm{C}$ with the indicated compounds. Lane 1: pRSII325 alone; Lane 2: pRSII325 + $1 \mathrm{mM}$ ascorbate; Lane 3: pRSII325 + $1 \mathrm{mM} \mathrm{H}_{2} \mathrm{O}_{2}$; Lane 4: pRSII325 + $0.1 \mathrm{mM} \mathrm{(1);} \mathrm{Lane} \mathrm{5:} \mathrm{pRSII325} \mathrm{+} 0.5 \mathrm{mM}$ (1); Lane 6: pRSII325 + $0.1 \mathrm{mM}$ (2); Lane 7: pRSII325 + $0.5 \mathrm{mM}$ (2); Lane 8: pRSII325 + $0.1 \mathrm{mM}(\mathbf{1})+1 \mathrm{mM}$ ascorbate; Lane 9: pRSII325 + $0.5 \mathrm{mM}(\mathbf{1})+1 \mathrm{mM}$ ascorbate; Lane 10: pRSII325 + $0.1 \mathrm{mM}(\mathbf{1})+1 \mathrm{mM}$ $\mathrm{H}_{2} \mathrm{O}_{2}$; Lane 11: pRSII325 + $0.5 \mathrm{mM}(1)+1 \mathrm{mM} \mathrm{H}_{2} \mathrm{O}_{2}$; Lane 12: pRSII325 + $0.1 \mathrm{mM}(2)+1 \mathrm{mM}$ ascorbate; Lane 13: pRSII325 + $0.5 \mathrm{mM}(2)+1 \mathrm{mM}$ ascorbate; Lane 14: pRSII325 + $0.1 \mathrm{mM}(2)+1 \mathrm{mM}$ $\mathrm{H}_{2} \mathrm{O}_{2}$; Lane 15: pRSII325 + $0.5 \mathrm{mM}(2)+1 \mathrm{mM} \mathrm{H}_{2} \mathrm{O}_{2}$.

\section{Materials and Methods}

\subsection{Reagents}

The chemicals for the synthesis of the complexes were purchased from Sigma-Aldrich (Darmstadt, Germany) (copper(II) perchlorate hexahydrate ( $\geq 99.99 \%$ trace metals basis), 2,2'-biyridine (bpy, 99\%), 1,10-phenantroline (phen, 99\%), 2,3-pentanedione (97\%) and 3-amino-4H-1,2,4-triazole (96\%)) and Merck (Darmstadt, Germany; dibenzo-18-crown-6ether, potassium superoxide) at reagent grade and were used as received, without further purification. The 5,7-dimethyl-1,2,4-triazolo[1,5- $a$ ]pyrimidine (dmtp) was synthesized by $[1+1\}$ condensation of 3-amino-4H-1,2,4-triazole and 2,3-pentanedione.

\subsection{Physical Measurements}

A EuroEA elemental analyzer (Perkin Elmer, Waltham, MA, USA) was used for chemical analyses (C, N, and H). Fourier Transform Infrared spectroscopy (FTIR) spectra were recorded in $\mathrm{KBr}$ pellets with a Tensor 37 spectrometer (Bruker, Billerica, MA, USA) in the $400-4000 \mathrm{~cm}^{-1}$ range. UV-Vis spectroscopy was performed in the solid state on a V 670 spectrophotometer (Jasco, Easton, MD, USA) with Spectralon as standard in the 200-1500 nm range. The X-band Electron Paramagnetic Resonance (EPR) spectroscopy measurements were carried out with a continuous wave X-Band EMX plus EPR spectrometer (Bruker AXS GmbH, Karlsruhe, Germany) equipped with a Bruker X-SHQ 4119HS-W1 $X$-Band resonator. The measurement parameters for the X-Band measurements, if not otherwise mentioned, were set as follows: microwave frequency $9.879 \mathrm{GHz}$, microwave power $2 \mathrm{~mW}$, modulation amplitude $0.1 \mathrm{mT}$, conversion time $26.67 \mathrm{~ms}$, time constant $10.24 \mathrm{~ms}$ at one scan. A continuous-wave Q-band Bruker ELEXSYS E500Q EPR spectrometer and an ER 5106 QT-W resonator were used for the Q-Band measurements. The measurement parameters for the Q-Band measurements, if not otherwise mentioned, were set as follows: 
microwave frequency $34.1507 \mathrm{GHz}$, microwave power $0.59 \mathrm{~mW}$, modulation amplitude $0.1 \mathrm{mT}$, conversion time $40 \mathrm{~ms}$, time constant $20.48 \mathrm{~ms}$ at one scan. All measurements were carried out at room temperature. Cyclic voltammograms were recorded at room temperature with an electrochemical system (potentiostat/galvanostat) Autolab PGSTAT 12 using the GPES (General Purpose Electrochemical System) software. These studies were carried out in inert atmosphere ( $\mathrm{Ar} 99.9999 \%$ ) in DMSO containing tetrabutylammonium perchlorate $\left(\mathrm{Bu}_{4} \mathrm{NClO}_{4}\right)$ 0.1 $\mathrm{M}$ as supporting electrolyte. The reference electrode was $\mathrm{Ag} / \mathrm{AgCl}$ separated from the solution by a bridge filled with a $0.1 \mathrm{M} \mathrm{Bu}_{4} \mathrm{NClO}_{4}$ solution in DMSO. The counter electrode was the platinum wire. A platinum disk electrode with $0.3 \mathrm{~mm}$ diameter was used as working electrode. The complexes concentration was $0.3 \mathrm{mM}$ in all measurements.

X-ray single crystal diffraction data sets for (1) were collected with a Bruker APEX II CCD diffractometer (Bruker AXS, Karlsruhe, Germany). Programs used: data collection: APEX3 V2016.1-0 [54]; cell refinement: SAINT V8.37A [54]; data reduction: SAINT V8.37A [54]; absorption correction, SADABS V2014/7 [54]; structure solution SHELXT2015 [55]; structure refinement SHELXL-2015 [56]. For compound (2), data sets were collected with a Nonius Kappa CCD diffractometer (Bruker Nonius B.V., Delft, Holland). Programs used: data collection, COLLECT [57]; data reduction Denzo-SMN [58]; absorption correction Denzo [59]; structure solution SHELXT-2015 [55]; structure refinement SHELXL2015 [56] and graphics, XP [60]. $R$-values are given for observed reflections, and $w \mathrm{R}^{2}$ values are given for all reflections.

Exceptions and special features: For compound (2), one perchlorate anion was found to be disordered over two positions in the asymmetric unit. Several restraints (SADI, SAME, ISOR, and SIMU) were used to improve refinement stability. Additionally, for compounds (1) and (2), two badly disordered water molecules were found in the asymmetrical unit and could not be satisfactorily refined. The SQUEEZE program [61] was therefore used to remove the effects of the solvent mathematically. The quoted formula and derived parameters do not include the squeezed solvent molecules. The crystallographic data for complexes (1) and (2) were deposited at the Cambridge Crystallographic Data Centre as a supplementary publication with CCDC numbers 2067846 and 2067847, respectively. These data can be obtained free of charge via http://www.ccdc.cam.ac.uk/data_request/cif (accessed on 29 August 2021), by e-mailing data_request@ccdc.cam.ac.uk, or by contacting the Cambridge Crystallographic Data Centre, 12 Union Road, Cambridge CB2 1EZ, UK; Fax: +44-1223-336033.

\subsection{Synthesis and Characterization of the Complexes}

$\left[\mathrm{Cu}(\mathrm{dpy})(\mathrm{dmtp})_{2}\left(\mathrm{OH}_{2}\right)\right]\left(\mathrm{ClO}_{4}\right)_{2} \cdot \mathrm{dmtp}(\mathbf{1})$ : To a solution, containing copper(II) perchlorate hexahydrate $(0.186 \mathrm{~g}, 0.5 \mathrm{mmol})$ in $50 \mathrm{~mL}$ ethanol, a solution containing dpy $(0.078 \mathrm{~g}$, $0.5 \mathrm{mmol}$ ) in $25 \mathrm{~mL}$ ethanol was added. This mixture was magnetically stirred at $50{ }^{\circ} \mathrm{C}$ for $2 \mathrm{~h}$, until the color turned blue, and then a solution containing dmtp $(0.222 \mathrm{~g}, 1.5 \mathrm{mmol})$ in $50 \mathrm{~mL}$ ethanol was added. The stirring of the reaction mixture continued for $4 \mathrm{~h}$, while the blue color intensified. Crystals suitable for X-ray analysis were obtained after three weeks by slow evaporation of this solution. Yield: $78 \%(0.34 \mathrm{~g})$. Analysis, found: $\mathrm{C}, 42.37$; $\mathrm{H}, 3.75 ; \mathrm{N}, 22.31 \%$; calculated for $\mathrm{CuC}_{31} \mathrm{H}_{34} \mathrm{~N}_{14} \mathrm{O}_{9} \mathrm{Cl}_{2}\left(\mathrm{M}_{\mathrm{w}}: 881.15 \mathrm{~g} \mathrm{~mol}^{-1}\right): \mathrm{C}, 42.26 ; \mathrm{H}$, 3.89; N, 22.25\%, IR (KBr pellet, $\left.\mathrm{cm}^{-1}\right): v\left(\mathrm{H}_{2} \mathrm{O}\right), 3511 \mathrm{w} ; \mathrm{v}(\mathrm{CH}), 3136 \mathrm{w}, 3112 \mathrm{w}, 3083 \mathrm{w}$; $v(\mathrm{C}=\mathrm{N})_{\text {trp }}, 1632 \mathrm{~m} ; v(\mathrm{C}=\mathrm{N})_{\text {pym }}, 1556 \mathrm{~m} ; \mathrm{v}(\mathrm{C}=\mathrm{N})+v(\mathrm{C}=\mathrm{C}), 1602 \mathrm{~m}, 1496 \mathrm{~m} ; v_{3}\left(\mathrm{ClO}_{4}\right), 1095 \mathrm{vs} ;$ $v_{4}\left(\mathrm{ClO}_{4}\right), 623 \mathrm{~m} ; \mathrm{v}(\mathrm{Cu}-\mathrm{N}), 417 \mathrm{w}, \mathrm{UV}-\mathrm{Vis}$ (solid, nm): $\pi \rightarrow \pi^{*}, 290,345 ; \mathrm{d}_{\mathrm{xz}}, \mathrm{d}_{\mathrm{yz}} \rightarrow \mathrm{d}_{\mathrm{z2}}, 590$; $\mathrm{d}_{\mathrm{xy}} \rightarrow \mathrm{d}_{\mathrm{z} 2}, 675$.

$\left[\mathrm{Cu}(\mathrm{phen})(\mathrm{dmtp})_{2}\left(\mathrm{OH}_{2}\right)\right]\left(\mathrm{ClO}_{4}\right)_{2} \cdot \mathrm{dmtp}$ (2): To a solution, containing copper(II) perchlorate hexahydrate $(0.186 \mathrm{~g}, 0.5 \mathrm{mmol})$ in $50 \mathrm{~mL}$ water, a solution containing phen $(0.090 \mathrm{~g}$, $1 \mathrm{mmol}$ ) in $25 \mathrm{~mL}$ ethanol was added. This mixture was magnetically stirred at $50{ }^{\circ} \mathrm{C}$ for $2 \mathrm{~h}$, until the color turned green, and then a solution containing dmtp $(0.222 \mathrm{~g}, 1.5 \mathrm{mmol})$ in $25 \mathrm{~mL}$ ethanol was added. The stirring of the reaction mixture continued for $4 \mathrm{~h}$, until the blue color was formed. Crystals suitable for X-ray analysis were obtained after two weeks by 
slow evaporation of this solution. Yield: 75\% (0.34 g). Analysis, found: C, 43.83; H, 3.75; N, 21.68\%; calculated forC $\mathrm{CuC}_{33} \mathrm{H}_{34} \mathrm{~N}_{14} \mathrm{O}_{9} \mathrm{Cl}_{2}\left(\mathrm{M}_{\mathrm{W}}\right.$ : $\left.905.17 \mathrm{~g} \mathrm{~mol}^{-1}\right)$ : C, 43.79; $\mathrm{H}, 3.79 ; \mathrm{N}, 21.66 \%$, IR (KBr pellet, $\left.\mathrm{cm}^{-1}\right): v\left(\mathrm{H}_{2} \mathrm{O}\right), 3517 \mathrm{w} ; \mathrm{v}(\mathrm{CH}), 3137 \mathrm{w}, 3110 \mathrm{w}, 3078 \mathrm{w} ; \mathrm{v}(\mathrm{C}=\mathrm{N})_{\operatorname{trp}}, 1630 \mathrm{~m}$; $v(\mathrm{C}=\mathrm{N})_{\text {pym }}, 1553 \mathrm{~m} ; \mathrm{v}(\mathrm{C}=\mathrm{N})+v(\mathrm{C}=\mathrm{C}), 1474 \mathrm{~m}, 1443 \mathrm{~m} ; \mathrm{v}_{3}\left(\mathrm{ClO}_{4}\right), 1099 \mathrm{vs} ; v_{4}\left(\mathrm{ClO}_{4}\right), 624 \mathrm{~m}$; $v(\mathrm{Cu}-\mathrm{N}), 432 \mathrm{w}$, UV-Vis (solid, nm): $\pi \rightarrow \pi^{*}, 265,360 ; \mathrm{d}_{\mathrm{xz}}, \mathrm{d}_{\mathrm{yz}} \rightarrow \mathrm{d}_{\mathrm{z} 2}, 610 ; \mathrm{d}_{\mathrm{xy}} \rightarrow \mathrm{d}_{\mathrm{z} 2}, 680$.

\subsection{Biological Characterization of Compounds}

Screening of the Antibacterial Properties

The antibacterial assays were carried out using two Gram-negative (Escherichia coli ATCC 25922, Pseudomonas aeruginosa ATCC 27853) and two Gram-positive (Staphylococcus aureus ATCC 25923, MRSA (meticillin-Resistant S. aureus) 388 (ATCC, American Type Culture Collection) bacteria.

The antimicrobial activity of the two complexes (1) and (2) was assessed using their minimum inhibitory concentration (MIC) by the broth microdilution method, as previously described by the Clinical and Laboratory Standard Institute (CLSI; M07-A9 document) [62]. A broth microdilution assay was performed in sterile 96-well plates using Muller-Hinton broth (Scharlau; MHB). The compounds solubilized in DSO $(1,000 \mu \mathrm{g} / \mathrm{mL})$ were serially diluted in $90 \mu \mathrm{L} \mathrm{MHB}$, in concentrations ranging between 500 and $0.97 \mu \mathrm{g} / \mathrm{mL}$. Overnight cultures were used to prepare suspension in phosphate-buffered saline ( $\mathrm{pH} 7.0$ ) to match a $0.5 \mathrm{McF}$ arland density. The bacterial suspensions were further diluted to 1:100 by adding $0.1 \mathrm{~mL}$ of bacterial suspension to $9.9 \mathrm{~mL}$ of MHB. A volume of $10 \mu \mathrm{L}$ of this dilution was added to each well of columns 1-10, containing different concentrations of the tested compounds. This resulted in the final desired inoculum of $105 \mathrm{cfu} / \mathrm{mL}$. Additionally, $10 \mu \mathrm{L}$ of the diluted bacterial suspension was added in column 11 (the growth control). A volume of $100 \mu \mathrm{L} \mathrm{MHB}$ was added to the microtiter plates' sterility control wells (column 12). After inoculation, the plates were incubated at $35 \pm 2{ }^{\circ} \mathrm{C}$ for $18 \mathrm{~h}$. Growth was measured as light absorbance $(620 \mathrm{~nm})$ in comparison to an uninoculated well (negative control). It was detected using a microtiter plate reader (Apollo LB 911ELISA (Berthold Technologies GmbH \& Co. KG, Waltham, MA, USA)). The MIC of each compound was defined as the lowest concentration required to inhibit bacterial growth.

The method for assessment of biofilm formation on polystyrene microtiter plates was based on previously published protocols $[18,63,64]$. The absorbance at $490 \mathrm{~nm}$ was measured with an Apollo LB 911ELISA (Berthold Technologies GmbH \& Co. KG, Waltham, MA, USA) reader. The minimal biofilm-eradication concentration (MBEC) was defined as the lowest concentration of antibiotics required to eradicate the biofilm. All experiments were performed in triplicate.

\subsection{In Vitro Cytotoxicity Assay}

\subsubsection{Cell Culture Conditions}

Human fibroblast cells (BJ-ATCC CRL-2522, USA) were grown in minimal essential medium (MEM) supplemented with $2 \mathrm{mM}$ L-Glutamine, 10\% fetal calf serum (FCS), 100 units $/ \mathrm{mL}$ of penicillin, and $100 \mu \mathrm{g} / \mathrm{mL}$ of streptomycin at $37^{\circ} \mathrm{C}$ in a humidified incubator under an atmosphere containing $5 \% \mathrm{CO}_{2}$. Mouse melanoma cells (B16-ATCC CRL6475, USA) were grown in DMEM (Dulbecco's Modified Eagle Medium) supplemented with similar reagents as MEM. All cell cultivation media and reagents were purchased from Biochrom AG (Berlin, Germany) and Sigma-Aldrich (Darmstadt, Germany).

\subsubsection{Cell Viability Assay}

Cell viability was evaluated using 3-(4,5-dimethylthiazol-2-yl)-2,5-diphenyltetrazolium bromide (MTT) assay as described previously [18]. First, the cells were seeded in 96-well plates (20000 cells/well) and cultured for $24 \mathrm{~h}$ in medium. After overnight incubation, the medium was changed, and the investigated sample at a concentration varying from 0.03 to $0.25 \mathrm{mg} / \mathrm{mL}$ was added for $24 \mathrm{~h}$. The negative control was represented by cells cultivated in a medium without the investigated compounds. Following incubation, the medium 
was changed, and the MTT solution was added to each well to a final concentration of $1 \mathrm{mg} / \mathrm{mL}$ and incubated for an additional $4 \mathrm{~h}$, at $37^{\circ} \mathrm{C}$. Finally, the medium was collected, and DMSO was used to dissolve the insoluble formazan product. The absorbance of the samples was recorded at $570 \mathrm{~nm}$ using a plate reader Mithras 940 (Berthold). The data were corrected for the background, and the percentage of viable cells was obtained using the equation:

$$
\text { Cell viability }=\left[\left(\mathrm{A}_{570} \text { of treated cells }\right) /\left(\mathrm{A}_{570} \text { of untreated cells }\right)\right] \times 100 \%
$$

The half-maximal inhibitory concentration $\left(\mathrm{IC}_{50}\right)$ was determined by fitting the data with a sigmoidal logistical equation using the software Origin 8.1 (Microcal Inc., Los Angeles, CA, USA).

\subsubsection{Lactate Dehydrogenase (LDH) Release Assay}

Membrane integrity after peptide treatment was assessed based on LDH release using a CytoTox 96 Non-Radioactive Cytotoxicity Assay (Promega), as previously described [65]. Cells were treated with different concentrations for $24 \mathrm{~h}$, and the medium was used for the LDH assay. Maximal LDH release was obtained by complete cell lysis induced by using $1 \%$ of Triton X-100. The absorption resulting from LDH activity was measured in a microplate reader Mithras 940 (Berthold) at $490 \mathrm{~nm}$, and the \% LDH was calculated as: [(corrected absorbance of the LDH released in treated cells)/(corrected absorbance of the total LDH released) ${ }^{*} 100 \%$.

\subsubsection{Phalloidin Staining and Cell Imaging}

According to the manufacturer protocol, the cytoskeleton actin filaments of $\mathrm{BJ}$ and B16 cells were stained with phalloidin-FITC (Sigma-Aldrich, St. Louis, MO, USA). Briefly, cells were washed with PBS (5 min, 3 times), fixed for $5 \mathrm{~min}$ with $3 \%$ paraformaldehyde, washed three times with PBS, permeabilized with $0.1 \%$ Triton X-100 in PBS for $15 \mathrm{~min}$, washed three times with PBS, stained with $20 \mu \mathrm{g} / \mathrm{mL}$ phalloidin-FITC at room temperature for $1 \mathrm{~h}$ and rewashed three times with PBS. The cell nucleus was stained with $8 \mu \mathrm{M}$ of Hoechst 33342 solution for $10 \mathrm{~min}$, washed three times with PBS, and finally, mounted and sealed on glass slides with FluorSave ${ }^{\mathrm{TM}}$ Reagent (Merck Millipore, Germany). The fluorescence images were acquired using an Andor DSD2 Confocal Unit (Andor, Ireland), mounted on an epifluorescence microscope, Olympus BX-51 (Olympus, Germany), equipped with a 40x and 100x objective and an appropriate DAPI/Hoechst filter cube (excitation filter $390 / 40 \mathrm{~m}$, dichroic mirror $405 \mathrm{~nm}$ and emission filter 452/45 nm) and GFP/FITC filter cube (excitation filter $466 / 40 \mathrm{~nm}$, dichroic mirror $488 \mathrm{~nm}$ and emission filter 525/54 nm).

\subsubsection{Superoxide Scavenging Ability}

The superoxide scavenging ability of the complexes was tested using the $\mathrm{KO}_{2} \mathrm{com}$ pound as a superoxide source combined with EPR spectroscopy. To carry out the experiments, a $10 \mu \mathrm{M}$ in DMSO solution of the complexes was mixed with different concentrations of $\mathrm{KO}_{2}$ in DMSO solution, and the EPR signal intensity changes were monitored. The $\mathrm{KO}_{2}$ was dissolved by complexation with dibenzo-18-crown-6-ether.

\subsubsection{Yeast Cells Experiments}

The Saccharomyces cerevisiae laboratory strain BY4741 (MATa; his $3 \Delta 1$; leu2 $\Delta 0$; met15 $\Delta 0$; ura $3 \Delta 0$ ) considered wild type (WT), and the isogenic strains $\operatorname{sod} 1 \Delta$ and $\operatorname{sod} 2 \Delta$ lacking the genes SOD1 (encoding $\mathrm{Cu} / \mathrm{Zn}$-superoxide dismutase) and SOD2 (encoding Mn-superoxide dismutase) were obtained from EUROSCARF (Frankfurt, Germany). Cells were maintained, manipulated and grown in a rich medium (YPD, $1 \% w / v$ yeast extract, $2 \% w / v$ peptone, $2 \%$ $w / v$ glucose; $2 \% w / v$ agar was added for solid media) or on synthetic complete medium (SC, $0.67 \% w / v$ yeast nitrogen base without amino acids, $2 \% w / v$ glucose) supplemented with the necessary amino acids [66]. Lysine drop-out medium (SC-Lys) was prepared similarly to SC, omitting lysine from the recipe. We added the complexes to autoclaved 
media from DMSO sterile stocks $(10 \mathrm{mM})$. An overnight culture was $10^{3}$-fold diluted in fresh medium and incubated $\left(200 \mathrm{rpm}, 30^{\circ} \mathrm{C}\right)$ until the culture reached a density of $5 \times 10^{5}$ cells. The compounds were added to the desired concentrations, and culture growth was monitored at $660 \mathrm{~nm}$ [67] in a 96-well multi-scanner plate reader equipped with a thermostat and shaker (Varioskan, Thermo Fischer Scientific, Vantaa, Finland). Three biological replicates were set for all determinations, and data were presented as average \pm standard error (SE). The Saccharomyces cerevisiae laboratory strain BY4741 (MATa; his $3 \Delta 1$; leu $2 \Delta 0$; met $15 \Delta 0$; ura3 $\Delta 0$ ) considered wild type (WT), and the isogenic strains sod $1 \Delta$ and sod $2 \Delta$ lacking the genes SOD1 (encoding $\mathrm{Cu} / \mathrm{Zn}$-superoxide dismutase) and SOD2 (encoding Mn-superoxide dismutase) were purchased from EUROSCARF (Frankfurt, Germany). Cells were maintained and manipulated and grown in YPD medium ( $1 \%$ $w / v$ yeast extract, $2 \% w / v$ peptone, $2 \% w / v$ glucose; $2 \% w / v$ agar was added for solid media) [66]. Complexes were added to autoclaved media from DMSO sterile stocks $(10 \mathrm{mM})$. To determine the effect of compounds on yeast growth, a fresh overnight preculture was $10^{3}$-fold diluted in YPD and incubated $\left(200 \mathrm{rpm}, 30^{\circ} \mathrm{C}\right)$ until the culture reached a density of $5 \times 10^{5}$ cells $/ \mathrm{mL}$. The compounds were added at the desired concentrations, and cell proliferation was monitored at $660 \mathrm{~nm}$ [60] in a 96-well multi-scanner auto reader plate reader equipped with a thermostat and shaker (Varioskan Thermo Fischer Scientific, Vantaa, Finland). All determinations were done on three biological replicates.

\subsubsection{Spectroscopic Determination of the Compounds' Interactions with DNA}

To determine if the compounds can interact with DNA, the 48,500 base-pairs genomic DNA from bacteriophage lambda ( $\lambda$-DNA, Promega, MA, USA) was used. A stock solution of $10 \mu \mathrm{M} \lambda$-DNA (base-pair concentration) was prepared in $10 \mathrm{mMTris} / \mathrm{HCl}$ buffer containing $1 \mathrm{mM} \mathrm{NaCl}$, $\mathrm{pH} 8$.

\subsubsection{Effect of DNA on Spectral Characteristics of Compounds}

To determine the DNA intercalating ability of complexes (1) and (2), we used the 48,500 base-pairs genomic DNA from the bacteriophage lambda ( $\lambda$-DNA, Promega, Madison, USA). A $10 \mu \mathrm{M} \lambda$-DNA (base-pair concentration) stock solution was prepared in $10 \mathrm{mM}$ Tris/ $\mathrm{HCl}$ buffer, $\mathrm{pH} 8$, containing $1 \mathrm{mM} \mathrm{NaCl}$. The UV-visible absorption titration experiments were done using a constant complex concentration $(5 \mu \mathrm{M})$. The concentrations of the $\lambda$-DNA solutions were gradually increased until a saturation state was achieved $[68,69]$. After DNA addition, the solutions were left to equilibrate for $5 \mathrm{~min}$ at room temperature before recording the spectra with a Jasco V-630 spectrophotometer. Stock solutions of compounds (1) and (2) were prepared in DMSO $(1 \mathrm{mM})$ and diluted to $5 \mu \mathrm{M}$ in $10 \mathrm{mM}$ Tris $/ \mathrm{HCl}$ containing $1 \mathrm{mM} \mathrm{NaCl}$, $\mathrm{pH} 8$.

The UV-Vis absorption titration experiments were done, keeping the complex concentration constant $(3 \mu \mathrm{M})$ and increasing the concentration of $\lambda$-DNA in Tris- $\mathrm{HCl} / \mathrm{NaCl}$ buffer solution at room temperature until a saturation state was achieved $[63,64]$. After DNA addition, the solutions were allowed to equilibrate for $5 \mathrm{~min}$ at room temperature. The UV-Vis absorption spectra were recorded with a Jasco V-630 spectrophotometer, using a $10 \mathrm{~mm}$ quartz cell. Stock solutions of compounds were prepared in DMSO $(1 \mathrm{mM})$ and diluted to $3 \mu \mathrm{M}$ in $10 \mathrm{mMTris} / \mathrm{HCl}$ containing $1 \mathrm{mM} \mathrm{NaCl}$, $\mathrm{pH} 8$.

\subsubsection{Effect of Compounds on the Fluorescence of $\lambda$-DNA/Ethidium Bromide Adduct}

The binding of complexes (1) and (2) to DNA was assayed by monitoring the quenching of fluorescence emitted by $\lambda$-DNA/ethidium bromide (EB) adduct $\left(\lambda_{\text {excit }}=510 \mathrm{~nm}\right.$, maximum emission at $\lambda_{\mathrm{em}}=601 \mathrm{~nm}$ ) in the presence of different concentrations of the tested compounds $[68,69]$. The fluorescence spectra were recorded in the range of $550-750 \mathrm{~nm}$ using a Thermo Fischer Scientific Varioskan Flash spectral scanning multimode reader (Vantaa, Finland). The spectra were recorded in suitable plates using $5 \mathrm{~nm}$ excitation and emission slits for all measurements. 
The binding of compounds to $\lambda$-DNA was assayed by monitoring the quenching of fluorescence emitted by $\lambda$-DNA/ethidium bromide (EB) adduct $\left(\lambda_{\text {excit }}=510\right.$, maximum emission at $\lambda_{\mathrm{em}}=601$ ). The $\lambda$-DNA solution was added to the EB solution, prepared in the same buffer, then increasing concentrations of compounds were added to EB-DNA [52,70]. The fluorescence spectra were recorded in the range of 550-750 nm using a Thermo Fischer Scientific Varioskan Flash spectral scanning multimode reader (Vantaa, Finland). The spectra were recorded in suitable plates using $5 \mathrm{~nm}$ excitation and emission slits for all measurements.

\subsubsection{Nuclease Activity Assay}

The nuclease activity of the compounds was determined using plasmid pRS325II DNA, which was a gift from Steven Haase (Addgene plasmid \#35467, 6835 base pairs) [71]. The plasmid was amplified in Escherichia coli by transforming One Shot ${ }^{\circledR}$ TOP10 chemically competent E. coli (Invitrogen, Thermo Fisher Scientific). The plasmid was isolated from positive colonies using a PureLink ${ }^{\mathrm{TM}}$ HiPure Plasmid Miniprep Kit (Invitrogen, Thermo Fisher Scientific). Plasmid (200 ng/sample) was exposed to complexes (1) and (2) in the presence of $1 \mathrm{mM}$ hydrogen peroxide (to exploit the $\mathrm{Cu}(\mathrm{II} / \mathrm{III})$ redox couple) or $1 \mathrm{mM}$ ascorbic acid (to exploit the $\mathrm{Cu}(\mathrm{I} / \mathrm{II})$ redox couple) [46]. The DNA cleavage experiments were done in a $9 / 1(v / v)$ ratio of $50 \mathrm{mM}$ Tris- $\mathrm{HCl}, \mathrm{pH} 8$, and DMSO. The samples were incubated for $1 \mathrm{~h}$ at $37^{\circ} \mathrm{C}$ before a bromophenol blue/xylene cyanol-based loading dye (Roth, Germany) was added. The samples were loaded onto a $1 \%(w / v)$ agarose gel containing $1 \mu \mathrm{g} / \mathrm{mL}$ EtBr in $1 \times$ TBE (Tris-boric acid-EDTA) buffer. Electrophoresis was performed at $50 \mathrm{~V}$ for $60 \mathrm{~min}$ in $1 \times \mathrm{TBE}$ buffer. The images of the fluorescent ethidium bromide-stained gels were captured using a gel documentation system (Doc-Print II, VilberLourmat, France). The cleavage experiments were done three times, with similar results. One representative gel is shown.

\section{Conclusions}

A novel series of copper(II) complexes with mixed ligands (5,7-dimethyl-1,2,4-triazolo [1,5-a]pyrimidine and 2,2'-bipyridine/1,10-phenanthroline) were stepwise synthesized, and structurally characterized. A complex supramolecular network is generated through $\pi-\pi$ stacking interactions realized between both 2,2'-bipyridine /1,10-phenanthroline belonging to different cationic units as well as between these and free triazolopyrimidine moieties. Complex (1) exhibits the ability to reduce the viability of B16 cells in a dosedependent manner and furthermore does not show any significant toxicity against BJ and Saccharomyces cerevisiae cells in the concentration ranges proven for the manifestation of biological activity. The value of the therapeutic index value and morphological modifications indicate that complex (1) was more susceptible than (2). Both complexes exhibited improved antimicrobial activity, as compared to the triazolopyrimidine ligand. Complex (2) was by far more active than (1) against the Gram-positive strains, susceptible or resistant, growing in planktonic or in biofilm states. Both MIC and MBEC values decreased in the case of complex (2) by 4 to 17 times compared to (1). The results suggest that both the antitumor and antimicrobial activity of these complexes involves intercalation into DNA strands as well as its damage through metallonuclease activity. Nuclease-like activity is enhanced in the presence of hydrogen peroxide, the complexes' interactions with this ROS also being proved by EPR and cyclic voltammetry data. Overall studies indicate the antitumor potential of complex (1) and the antibacterial potential of complex (2), especially against the Gram positive strains. As a result, these species will be further studied in order to improve their solubility, and consequently their activity, by their inglobation in organic matrix.

Supplementary Materials: The following are available online, Figure S1: Dimer type formation between two cations trough $\pi \cdots \pi$ interactions involving the 1,10-phenantroline ligands in (2), Figure S2: Dimer-type formation between two dmtp ligands involving $\mathrm{CH} \cdots \mathrm{N}$ interactions in (2), Figure S3: Excerpt of the packing diagram of compound (2) presenting the formation of linear chains 
along the $b$-axis trough $\pi \cdots \pi, \mathrm{OH} \cdots \mathrm{N}$ and $\mathrm{CH} \cdots \mathrm{N}$ interactions between the cations and the dmtp free moieties, Figure S4: IR spectra of dmtp and complexes, Figure S5: UV-Vis spectra of complex (1) (dark blue), bpy (yellow) and dmtp (orange), Figure S6: UV-Vis spectra of complex (2) (dark blue), phen (yellow) and dmtp (orange), Table S1: Continuous shape measure for the coordination polyhedron around the $\mathrm{Cu}(\mathrm{II})$ atom, Table S2: Non-covalent intermolecular interactions in compound $1\left(\AA\right.$ and $\left.{ }^{\circ}\right)$, Table S3: Non-covalent intermolecular interactions in compound (2) $\left(\AA\right.$ and $\left.{ }^{\circ}\right)$.

Author Contributions: Conceptualization, I.C.F., M.B. (Mihaela Bacalum), M.C.C., M.B. (Mihaela Badea) and R.O.; Data curation, L.L.R., M.B. (Mihaela Bacalum), A.M.R., C.D., L.M., M.P., M.B. (Mihaela Badea), E.E.I. and R.O.; Formal analysis, L.L.R., I.C.F., M.B. (Mihaela Bacalum), M.R., A.M.R., M.B. (Mihaela Badea), E.E.I. and R.O.; Investigation, L.L.R., M.R., A.M.R., C.D., L.M., M.P., E.E.I. and R.O.; Supervision, M.B. (Mihaela Bacalum), M.C.C., M.B. (Mihaela Badea) and R.O.; Validation, I.C.F., M.B. (Mihaela Bacalum) and M.C.C.; Writing-original draft, I.C.F., M.B., A.M.R., C.D., L.M. and R.O.; Writing-review and editing, I.C.F., M.B. (Mihaela Bacalum), A.M.R., C.D., M.C.C. and R.O. All authors have read and agreed to the published version of the manuscript.

Funding: This research received no external funding.

Institutional Review Board Statement: Not applicable.

Informed Consent Statement: Not applicable.

Data Availability Statement: Not applicable.

Acknowledgments: The financial support of the CNFIS-FDI-2021-0405 is gratefully acknowledged.

Conflicts of Interest: The authors declare no conflict of interest.

Sample Availability: Samples of the compounds (1) and (2) are available from the authors.

\section{References}

1. Pinheiro, S.; Pinheiro, E.M.C.; Muri, E.M.F.; Pessôa, J.C.; Cadorini, M.A.; Greco, S.J. Biological activities of [1,2,4]triazolo[1,5a]pyrimidines and analogs. Med. Chem. Res. 2020, 29, 1751-1776. [CrossRef]

2. Huo, J.-L.; Wang, S.; Yuan, X.-H.; Yu, B.; Zhao, W.; Liu, H.-M. Discovery of $[1,2,4]$ triazolo[1,5-a]pyrimidines derivatives as potential anticancer agents. Eur. J. Med. Chem. 2021, 211, 113108. [CrossRef] [PubMed]

3. Safaria, F.; Bayat, M.; Nasri, S.; Karami, S. Synthesis and evaluation of anti-tumor activity of novel triazolo[1,5-a]pyrimidine on cancer cells by induction of cellular apoptosis and inhibition of epithelial-to-mesenchymal transition process. Bioorg. Med. Chem. Lett. 2020, 30, 127111. [CrossRef] [PubMed]

4. Huang, B.; Kang, D.; Tian, Y.; Daelemans, D.; De Clercq, E.; Pannecouque, C.; Zhan, P.; Liu, X. Design, synthesis, and biological evaluation of piperidinylsubstituted $[1,2,4]$ triazolo[1,5- $a]$ pyrimidine derivatives as potential anti-HIV-1 agents with reduced cytotoxicity. Chem. Biol. Drug. Des. 2021, 97, 67-76. [CrossRef]

5. Kavitha, K.; Sivakumar, S.; Ramesh, B. 1,2,4 triazolo[1,5-a] pyrimidin-7-ones as novel SARS-CoV-2 Main protease inhibitors: In silico screening and molecular dynamics simulation of potential COVID-19 drug candidates. Biophys. Chem. 2020, $267,106478$. [CrossRef]

6. Mohamed, M.A.A.; Bekhit, A.A.; Abd Allah, O.A.; Kadry, A.M.; Ibrahim, T.M.; Bekhit, S.A.; Amagase, K.; El-Saghier, A.M.M. Synthesis and antimicrobial activity of some novel 1,2-dihydro-[1,2,4]triazolo[1,5- $a$ ]pyrimidines bearing amino acid moiety. RSC Adv. 2021, 11, 2905. [CrossRef]

7. Abd El-Aleam, R.H.; George, R.F.; Hassan, G.S.; Abdel-Rahman, H.M. Synthesis of 1,2,4-triazolo[1,5-a]pyrimidine derivatives: Antimicrobial activity, DNA Gyrase inhibition and molecular docking. Bioorg. Chem. 2020, 94, 103411. [CrossRef]

8. Oukoloff, K.; Nzou, G.; Varricchio, C.; Lucero, B.; Alle, T.; Kovalevich, J.; Monti, L.; Cornec, A.-S.; Yao, Y.; James, M.J. Evaluation of the Structure-Activity Relationship of MicrotubuleTargeting 1,2,4-Triazolo[1,5-a]pyrimidines Identifies New Candidates for Neurodegenerative Tauopathies. J. Med. Chem. 2021, 64, 1073-1102. [CrossRef]

9. Richardson, C.M.; Williamson, D.S.; Parratt, M.J.; Borgognoni, J.; Cansfield, A.D.; Dokurno, P.; Francis, G.L.; Howes, R.; Moore, J.D.; Murray, J.B.; et al. Triazolo[1,5-a] pyrimidines as novel CDK2 inhibitors: Protein structure-guided design and SAR. Bioorg. Med. Chem. Lett. 2006, 16, 1353-1357. [CrossRef]

10. Kim, N.D.; Park, E.S.; Kim, Y.H.; Moon, S.K.; Lee, S.S.; Ahn, S.K.; Yu, D.Y.; No, K.T.; Kim, K.H. Structure-based virtual screening of novel tubulin inhibitors and their characterization as anti-mitotic agents. Bioorg. Med. Chem. 2010, 18, 7092-7100. [CrossRef]

11. Wang, S.; Zhao, L.J.; Zheng, Y.C.; Shen, D.D.; Miao, E.F.; Qiao, X.P.; Zhao, L.J.; Liu, Y.; Huang, R.; Yu, B.; et al. Design, synthesis and biological evaluation of $[1,2,4]$ triazolo[1,5-a]pyrimidines as potent lysine specific demethylase 1 (LSD1/KDM1A) inhibitors. Eur. J. Med. Chem. 2017, 125, 940-951. [CrossRef] [PubMed]

12. Hassan, A.Y.; Sarg, M.T.; Bayoumi, A.H.; El-Deeb, M.A. Synthesis and anticancer evaluation of some novel 5-amino[1,2,4]triazole derivatives. J. Heterocycl. Chem. 2018, 55, 1450-1478. [CrossRef] 
13. Dawood, D.H.; Nossier, E.S.; Ali, M.M.; Mahmoud, A.E. Synthesis and molecular docking study of new pyrazole derivatives as potent anti-breast cancer agents targeting VEGFR-2 kinase. Bioorg. Chem. 2020, 101, 103916. [CrossRef] [PubMed]

14. Luo, Y.; Zhang, S.; Liu, Z.J.; Chen, W.; Fu, J.; Zeng, Q.F.; Zhu, H.L. Synthesis and antimicrobical evaluation of a novel class of 1,3,4thiadiazole: Derivatives bearing 1,2,4-triazolo[1,5-a] pyrimidine moiety. Eur. J. Med. Chem. 2013, 64, 54-61. [CrossRef]

15. Lahmidi, S.; Anouar, E.H.; El Hamdaoui, L.; Ouzidan, Y.; Kaur, M.; Jasinski, J.P.; Sebbar, N.K.; Essassi, E.M.; El Moussaouit, M. Synthesis, crystal structure, spectroscopic characterization, hirshfeld surface analysis, DFT calculation and antibacterial activity of ethyl 2-(4-vinylbenzyl)-2-(5- methyl-[1,2,4]triazolo [1,5-a] pyrimidin-7-yl)-3-(4-vinylphenyl) propanoate. J. Mol. Struct. 2019, 1191, 66-75. [CrossRef]

16. Badea, M.; Uivarosi, V.; Olar, R. Improvement in the Pharmacological Profile of Copper Biological Active Complexes by Their Incorporation into Organic or Inorganic Matrix. Molecules 2020, 25, 5830. [CrossRef]

17. Salas, J.M.; Caballero, A.B.; Esteban-Parra, G.M.; Méndez-Arriaga, J.M. Leishmanicidal and Trypanocidal Activity of Metal Complexes with 1,2,4-Triazolo[1,5-a]pyrimidines: Insights on their Therapeutic Potential against Leishmaniasis and Chagas Disease. Curr. Med. Chem. 2017, 24, 2796-2806. [CrossRef]

18. Rostas, A.M.; Badea, M.; Ruţă, L.L.; Farcaşanu, I.C.; Maxim, C.; Chifiriuc, M.C.; Popa, M.; Luca, M.; Čelan Korošin, N.; Cerc Korošec, R.; et al. Copper(II) complexes with mixed heterocycle ligands as promising antibacterial and antitumor species. Molecules 2020, 25, 3777. [CrossRef]

19. Méndez-Arriaga, J.M.; Oyarzabal, I.; Escolano, G.; Rodríguez-Diéguez, A.; Sánchez-Moreno, M.; Salas, J.M. In vitro leishmanicidal and trypanocidal evaluation and magnetic properties of 7-amino-1,2,4-triazolo[1,5-a]pyrimidine Cu(II) complexes. J. Inorg. Biochem. 2018, 180, 26-32. [CrossRef] [PubMed]

20. Méndez-Arriaga, J.M.; Oyarzabal, I.; Martín-Montes, Á.; García-Rodríguez, J.; Quirós, M.; Sánchez-Moreno, M. First example of antiparasitic activity influenced by thermochromism: Leishmanicidal evaluation of 5,7-dimethyl-1,2,4-triazolo[1,5-a]pyrimidine metal complexes. Med. Chem. 2020, 16, 422-430. [CrossRef]

21. Caballero, A.B.; Rodríguez-Dieguez, A.; Quiros, M.; Salas, J.M.; Huertas, O.; Ramírez-Macías, I.; Olmo, F.; Marín, C.; ChavesLemaur, G.; Gutierrez-Sánchez, R.; et al. Triazolopyrimidine compounds containing first-row transition metals and their activity against the neglected infectious Chagas disease and leishmaniasis. Eur. J. Med. Chem. 2014, 85, 526-534. [CrossRef]

22. Méndez-Arriaga, J.M.; Rodríguez-Diéguez, A.; Sánchez-Moreno, M. In vitro leishmanicidal activity of copper (II) 5,7-dimethyl1,2,4-triazolo[1,5-a]pyrimidine complex and analogous transition metal series. Polyhedron 2020, 176, 114272. [CrossRef]

23. Ramírez-Macías, I.; Marín, C.; Salas, J.M.; Caballero, A.; Rosales, M.; Villegas, N.J.; Rodríguez-Dieguez, A.; Barea, E.; SánchezMoreno, M. Biological activity of three novel complexes with the ligand 5-methyl-1,2,4-triazolo[1,5-a]pyrimidin-7(4H)-one against Leishmania spp. J. Antimicrob. Chemother. 2011, 66, 813-819. [CrossRef] [PubMed]

24. Boutaleb-Charki, S.; Marín, C.; Maldonado, C.R.; Rosales, M.J.; Urbano, J.; Guitierrez-Sánchez, R.; Quirós, M.; Salas, J.M.; Sánchez-Moreno, M. Copper (II) Complexes of [1,2,4]Triazolo [1,5-a]Pyrimidine Derivatives as Potential Anti-Parasitic Agents. Drug Met. Lett. 2009, 3, 35-44. [CrossRef] [PubMed]

25. Caballero, A.B.; Marín, C.; Ramírez-Macías, I.; Rodríguez-Diéguez, A.; Quirós, M.; Salas, J.M.; Sánchez-Moreno, M. Structural consequences of the introduction of 2,2'-bipyrimidine as auxiliary ligand in triazolopyrimidine-based transition metal complexes. In vitro antiparasitic activity. Polyhedron 2012, 33, 137-144. [CrossRef]

26. Calu, L.; Badea, M.; Cerc Korošec, R.; Bukovec, P.; Daniliuc, C.C.; Chifiriuc, M.C.; Măruţescu, L.; Ciulică, C.; Şerban, G.; Olar, $\mathrm{R}$. Thermal behaviour of some novel biologically active complexes with a triazolopyrimidine pharmacophore. J. Therm. Anal. Calorim. 2017, 127, 697-708. [CrossRef]

27. Olar, R.; Calu, L.; Badea, M.; Chifiriuc, M.C.; Bleotu, C.; Velescu, B.; Stoica, O.; Ioniţă, G.; Stanică, N.; Silvestro, L.; et al. Thermal behaviour of some biologically active species based on complexes with a triazolopyrimidine pharmacophore. J. Therm. Anal. Calorim. 2017, 127, 685-696. [CrossRef]

28. Badea, M.; Calu, L.; Celan Korosin, N.; David, I.G.; Chifiriuc, M.C.; Bleotu, C.; Ioniţă, G.; Silvestro, L.; Maurer, M.; Olar, R. Thermal behaviour of some biological active perchlorate complexes with a triazolopyrimidine derivative. J. Therm. Anal. Calorim. 2018, 134, 665-677. [CrossRef]

29. Olar, R.; Badea, M.; Bacalum, M.; Raileanu, M.; Ruta, L.L.; Farcasanu, I.C.; Rostas, A.M.; Vlaicu, I.D.; Popa, M.; Chifiriuc, M.C. Antiproliferative and antibacterial properties of biocompatible copper(II) complexes bearing chelating N,N-heterocycle ligands and potential mechanisms of action. Biometals 2021, 34, 1155-1172. [CrossRef] [PubMed]

30. Hathaway, B.J. Oxyanions. In Comprehensive Coordination Chemistry, 1st ed.; Wilkinson, G., Gillard, R.D., McCleverty, J.A., Eds.; Pergamon Press: Oxford, UK, 1987; pp. 413-434.

31. Lever, A.B.P. Inorganic Electronic Spectroscopy; Elsevier: Amsterdam, The Netherlands, 1986; pp. 555-572.

32. Abragam, A.; Bleaney, B. Electron Paramagnetic Resonance of Transition Ions; Oxford University Press: Oxford, UK, 2012 ; pp. 455-466.

33. Santini, C.; Pellei, M.; Gandin, V.; Porchia, M.; Tisato, F.; Marzano, C. Advances in copper complexes as anticancer agents. Chem. Rev. 2014, 114, 815-862. [CrossRef] [PubMed]

34. Domingues, B.; Lopes, J.M.; Soares, P.; Pópulo, H. Melanoma treatment in review. Immunotargets Ther. 2018, 7, 35-49. [CrossRef]

35. Monti, E.; Paracchini, L.; Piccinini, F.; Malatesta, V.; Morazzoni, F.; Supino, R. Cardiotoxicity and antitumor activity of a copper(II)-doxorubicin chelate. Cancer. Chemother. Pharmacol. 1990, 25, 333-336. [CrossRef] 
36. Collins, M.; Ewing, D.; Mackenzie, G.; Sinn, E.; Sandbhor, U.; Padhye, S.; Padhye, S. Metal complexes as anticancer agents 2. Synthesis, spectroscopy, magnetism, electrochemistry, X-ray crystal structure and antimelanomal activity of the copper (II) complex of 5-amino-1-tolylimidazole-4-carboxylate in B16F10 mouse melanoma cells. Inorg. Chem. Commun. 2000, 3, 453-457. [CrossRef]

37. Leovac, V.M.; Bogdanović, G.A.; Jovanović, L.S.; Joksović, L.; Marković, V.; Joksović, M.D.; Misirlić Denčić, S.; Isaković, A.; Marković, I.; Heinemann, F.W.; et al. Synthesis, characterization and antitumor activity of polymeric copper(II) complexes with thiosemicarbazones of 3-methyl-5-oxo-1-phenyl-3-pyrazolin-4-carboxaldehyde and 5-oxo-3-phenyl-3-pyrazolin-4carboxaldehyde. J. Inorg. Biochem. 2011, 105, 1413-1421. [CrossRef] [PubMed]

38. Ruan, B.-F.; Liang, Y.-K.; Liu, W.-D.; Wu, J.-Y.; Tian, Y.-P. Synthesis, characterization, and antitumor activities of two copper(II) complexes with pyrazole derivatives. J. Coord. Chem. 2012, 65, 2127-2134. [CrossRef]

39. Mroueh, M.; Daher, C.; Hariri, E.; Demirdjian, S.; Isber, S.; Choi, E.S.; Mirtamizdoust, B.; Hammud, H.H. Magnetic property, DFT calculation, and biological activity of bis $\left[\left(\mu_{2}\right.\right.$-chloro)chloro(1,10-phenanthroline)copper(II)]complex. Chem. Biol. Interact. 2015, 231, 53-60. [CrossRef]

40. Borges, L.J.H.; Bull, E.S.; Fernandes, C.; Horn, A., Jr.; Azeredo, N.F.; Resende, J.A.L.C.; Freitas, W.R.; Carvalho, E.C.Q.; Lemos, L.S.; Jerdy, H.; et al. In vitro and in vivo studies of the antineoplastic activity of copper (II) compounds against human leukemia THP-1 and murine melanoma B16-F10 cell lines. Eur. J. Med. Chem. 2016, 123, 128-140. [CrossRef]

41. Gurudevaru, C.; Gopalakrishnan, M.; Senthilkumar, K.; Hemachandran, H.; Siva, R.; Srinivasan, T.; Velmurugan, D.; Shanmugan, S. Synthesis and structural and DNA binding studies of mono-and dinuclear copper (II) complexes constructed with- O and- N donor ligands: Potential anti-skin cancer drugs. Appl. Organometal. Chem. 2017, 31, e3998. [CrossRef]

42. Kalinowska-Lis, U.; Szabłowska-Gadomska, I.; Lisowska, K.; Ochocki, J.; Małecki, M.; Felczak, A. Cytotoxic and Antimicrobial Properties of Copper(II) Complexes of Pyridine and Benzimidazole Derivatives. Z. Anorg. Allg. Chem. 2017, 643, 993-998. [CrossRef]

43. Mariani, D.; Ghasemishahrestani, Z.; Freitas, W.; Pezzuto, P.; Costa-da-Silva, A.C.; Tanuri, A.; Kanashiro, M.M.; Fernandes, C.; Horn, A., Jr.; Pereira, M.D. Antitumoral synergism between a copper(II) complex and cisplatin improves in vitro and in vivo anticancer activity against melanoma, lung and breast cancer cells. Biochim. Biophys. Acta 2021, 1865, 129963. [CrossRef]

44. European Centre for Disease Prevention and Control. Antimicrobial Resistance in the EU/EEA (EARS-Net)—Annual Epidemiological Report 2019; ECDPC: Stockholm, Sweden, 2020.

45. Boswihi, S.S.; Udo, E.E.; AlFouzan, W. Antibiotic resistance and typing of the methicillin-resistant Staphylococcus aureus clones in Kuwait hospitals, 2016-2017. BMC Microbiol. 2020, 20, 314. [CrossRef] [PubMed]

46. Brahma, U.; Kothari, R.; Sharma, P.; Bhandari, V. Antimicrobial and anti-biofilm activity of hexadentated macrocyclic complex of copper (II) derived from thiosemicarbazide against Staphylococcus aureus. Sci. Rep. 2018, 8, 8050. [CrossRef] [PubMed]

47. Valliammai, A.; Sethupathy, S.; Priya, A.; Selvaraj, A.; Bhaskar, J.P.; Krishnan, V.; Pandian, S.K. 5-Dodecanolide interferes with biofilm formation and reduces the virulence of Methicillin-resistant Staphylococcus aureus (MRSA) through up regulation of agr system. Sci. Rep. 2019, 9, 13744. [CrossRef]

48. Culotta, V.C. Superoxide dismutase, oxidative stress, and cell metabolism. Curr. Top. Cell. Regul. 2000, 36, 117-132. [CrossRef] [PubMed]

49. Culotta, V.C.; Sturtz, L.A. Superoxide dismutase null mutants of baker's yeast, Saccharomyces cerevisiae. Methods Enzymol. 2002, 349, 167-172. [CrossRef]

50. Dumitru, I.; Ene, C.D.; Ofiteru, A.M.; Paraschivescu, C.; Madalan, A.M.; Baciu, I.; Farcasanu, I.C. Identification of [CuCl(acac)(tmed)], a copper(II) complex with mixed ligands, as a modulator of $\mathrm{Cu}$, Zn superoxide dismutase (Sod1p) activity in yeast. J. Biol. Inorg. Chem. 2012, 17, 961-974. [CrossRef]

51. Satyanarayana, S.; Dabrowiak, J.C.; Chaires, J.B. Tris (phenanthroline) ruthenium (II) enantiomer interactionswith DNA: Mode and specificity of binding. Biochemistry 1993, 32, 2573-2584. [CrossRef]

52. Nyarko, E.; Hanada, N.; Habib, A.; Tabata, M. In vitro toxicity of palladium(II) and gold(III) porphyrins and their aqueous metal ion counterparts on Trypanosoma brucei growth. Chem. Biol. Interact. 2004, 48, 19-25. [CrossRef] [PubMed]

53. Bhattacharyya, S.; Sarkar, A.; Dey, S.K.; Jose, G.P.; Mukherjee, A.; Sengupta, T.K. Copper (II) complex of methionine conjugated bis-pyrazole based ligand promotes dual pathway for DNA cleavage. Dalton. Trans. 2013, 42, 11709-11719. [CrossRef]

54. Bruker AXS. Crystallography Software Suite APEX3, SAINT and SADABS; Bruker AXS Inc.: Madison, WI, USA, 2016.

55. Sheldrick, G.M. SHELXT-Integrated space-group and crystal-structure determination. Acta Crystallogr. 2015, A71, 3-8. [CrossRef]

56. Sheldrick, G.M. Crystal structure refinement with SHELXL. Acta Crystallogr. 2015, C71, 3-8. [CrossRef]

57. Hooft, R.W.W. Program for Collecting Data on CCD Area Detectors; Nonius, B.V., Ed.; ACSECI: Delft, The Netherlands, 1998.

58. Otwinowski, Z.; Minor, W. Processing of X-ray diffraction data collected in oscillation mode. Methods Enzymol. 1997, 276, 307-326. [CrossRef]

59. Otwinowski, Z.; Borek, D.; Majewski, W.; Minor, W. Multiparametric scaling of diffraction intensities. Acta Crystallogr. 2003, A59, 228-234. [CrossRef]

60. XP_-Interactive Molecular Graphics, Version 5.1; Bruker AXS Inc.: Madison, WI, USA, 1998.

61. Spek, A.L. PLATON SQUEEZE: A tool for the calculation of the disordered solvent contribution to the calculated structure factors. Acta Crystallogr. 2015, C71, 9-18. [CrossRef] 
62. Clinical and Laboratory Standards Institute (CLSI). Methods for Dilution Antimicrobial Susceptibility Test for Bacteria That Grow Aerobically, Document M7-A6. 2018. Available online: https://clsi.org/media/1928/m07ed11_sample.pdf (accessed on 2 September 2018).

63. Badea, M.; Vlaicu, I.D.; Olar, R.; Constand, M.; Bleotu, C.; Chifiriuc, M.; Marutescu, L.; Grecu, M.N.; Marinescu, D. Thermal behaviour and characterisation of new biologically active $\mathrm{Cu}(\mathrm{II})$ complexes with benzimidazole as main ligand. J. Therm. Anal. Calorim. 2014, 118, 1119-1133. [CrossRef]

64. Vlaicu, I.D.; Constand, M.; Olar, R.; Marinescu, D.; Grecu, M.N.; Lazar, V.; Chifiriuc, M.; Badea, M. Thermal stability of new biologic active copper(II) complexes with 5,6-dimethylbenzimidazole. J. Therm. Anal. Calorim. 2013, 113, 1369-1377. [CrossRef]

65. Bacalum, M.; Janosi, L.; Zorila, F.; Tepes, A.M.; Ionescu, C.; Bogdan, E.; Hadade, N.; Craciun, L.; Grosu, I.; Turcu, I.; et al. Modulating short tryptophan- and argininerich peptides activity by substitution with histidine. Biochim. Biophys. Acta 2017, 1861, 1844-1854. [CrossRef]

66. Sherman, F. Getting started with yeast. Methods Enzymol. 2002, 350, 3-41. [CrossRef] [PubMed]

67. Amberg, D.C.; Burke, D.J.; Strathern, J.N. Methods in Yeast Genetics. A Cold Spring Harbor Laboratory Course Manual; Cold Spring Harbor Laboratory Press: New York, NY, USA, 2005.

68. Ferreira, B.L.; Brandao, P.; Meireles, M.; Martel, F.; Correia-Branco, A.; Fernandes, D.M.; Santos, T.M.; Félix, V. Synthesis, structural characterization, cytotoxic properties and DNA binding of a dinuclear copper (II) complex. J. Inorg. Biochem. 2016, 161, 9-17. [CrossRef]

69. Ma, T.; Xu, J.; Wang, Y.; Yu, H.; Yang, Y.; Liu, Y.; Ding, W.; Zhu, W.; Chen, R.; Ge, Z.; et al. Ternary copper(II) complexes with amino acid chains and heterocyclic bases: DNA binding, cytotoxic and cell apoptosis induction properties. J. Inorg. Biochem. 2015, 144, 38-46. [CrossRef] [PubMed]

70. Rajendran, N.; Kamatchi, N.; Periyasamy, A.; Solomon, V. DNA-interaction, antibacterial and in vitro cytotoxic properties of copper(II) complexes bearing (E)-2-(2-(benzo[d]thiazol-2-ylthio)-1-phenylethylidene)thiosemicarbazone and diimine co-ligands. J. Coord. Chem. 2020, 73, 969-985. [CrossRef]

71. Chee, M.K.; Haase, S.B. New and redesigned pRS plasmid shuttle vectors for genetic manipulation of Saccharomyces cerevisiae. G3 Genes. Genom. Genet. 2012, 2, 515-526. [CrossRef] [PubMed] 